\title{
The Relationship between a Western Amazonian Society and Domesticated Sedges (Cyperus spp.)
}

\author{
Monika Kujawska ${ }^{*, 1}$, Fernando Zamudio ${ }^{2}$, Joaquina Albán-Castillo ${ }^{3}$, and \\ JOANNA SOSNOWSKA ${ }^{4}$ \\ ${ }^{1}$ University of Lodz, Institute of Ethnology and Cultural Anthropology, Lodz, Poland \\ ${ }^{2}$ Instituto Multidisciplinario de Biología Vegetal (CONICET-UNC), Córdoba, Argentina \\ ${ }^{3}$ Universidad Nacional Mayor de San Marcos. Museo de Historia Natural, Lima, Peru \\ ${ }^{4}$ Museum of Ethnography in Krakow, Krakow, Poland \\ *Corresponding author; e-mail: monika.kujawska@uni.lodz.pl
}

\begin{abstract}
The article discusses the relationships between the Ashaninka people from Peruvian Amazonia and the domesticated sedges (Cyperus spp.) cultivated in almost every Ashaninka home garden, and mostly exchanged within family circles. An over-differentiation phenomenon is observed, in which four species of Cyperus correspond to 86 folk species. The names of folk species are formed by secondary lexemes, composed of a semantically active constituent and a generic suffix (i)benki. The names contain mnemonic cues to differentiate otherwise morphologically similar plants, and their meanings correspond to Ashaninka ontological categories, thus revealing many levels of connectivity between them and non-humans. The wide scope of specific uses (approx. 60 registered) assigned to Cyperus spp. is only partly supported by phytochemicals and ergot alkaloids in the fungus-infested sedges. The key to understanding the ibenkis (Cyperus) agency lies in local cosmologies, in which domesticated sedges are viewed as plant-persons and kin. The Ashaninka are engaged in producing the bodies of their kin, the ibenki. Simultaneously, ibenki are powerful allies in restoring harmonious social relations and protecting people against the intentional actions of other humans and non-humans.
\end{abstract}

El presente artículo analiza las relaciones entre el grupo asháninka de la Amazonía peruana y las juncias domesticadas (Cyperus spp.). Estas son plantas cultivadas en casi todos los huertos hogareños asháninka, y son mayormente intercambiadas dentro de los círculos familiares. Se observa un fenómeno de sobrediferenciación, en el que cuatro especies de Cyperus corresponden a 86 taxones vernáculos (etnoespecies). Los nombres de los taxones vernáculos están formados por lexemas secundarios, compuestos por un componente semánticamente activo y un sufijo genérico (i)benki. Los nombres contienen señales mnemotécnicas para diferenciar plantas morfológicamente similares, y sus significados corresponden a categorías ontológicas asháninka, revelando diversos niveles de conectividad entre los asháninkay no humanos. La amplia gama de usos específicos (aprox. 60 registrados) asignados a Cyperus spp. sólo están parcialmente respaldados por factores fitoquímicos propios de los alcaloides del cornezuelo de centeno que se encuentran en los hongos que infestan las juncias domesticadas. La clave para entender la agencia de los ibenki (Cyperus) se encuentra en las cosmologías locales, en las que las juncias domesticadas se consideran personas-plantas y parientes de los asháninka. En este sentido los asháninka se dedican a producir los cuerpos de sus parientes, los ibenki. Simultáneamente, los ibenki son aliados poderosos necesarios para restaurar relaciones sociales armoniosas y proteger a las personas contra las acciones intencionales de otros humanos y no humanos.

\footnotetext{
${ }^{1}$ Received 6 March 2020; accepted 3 August 2020; published online 20 August 2020
} 
Key Words: Cyperus, More-than-utility approach, Ethnobotany, Ontological perspective, Ashaninka, Peruvian Amazon.

\section{Introduction}

Native Amazonian groups rely on a great number of medicinal plants in their home medicine, midwifery, and complementary healing such as minisaunas (Giovannini 2015; Luziatelli et al. 2010; Milliken et al. 1999; Shepard 1998; Valadeau et al. 2010). They often resort to home garden plants, where a diversity of domesticated species is notably present (e.g., Cyperus spp., Justicia spp., Zingiber spp.) (Bennett, 1992; Caballero-Serrano et al. 2019; Díaz-Reviriego et al. 2016; Shepard 1998; Valadeau et al. 2010; Wezel and Ohl 2005). The agency of these plants from the perspective of local cosmologies still poses a challenge for anthropology and ethnobotany. This article addresses the entanglement between the indigenous Ashaninka people from Peruvian Amazonia and one particular group of plants-domesticated sedges (Cyperus spp.) from the Cyperaceae family. We use a more-than-utility approach in arguing that domesticated sedges are kin and powerful allies of the Ashaninka people, and participate in maintaining the bodies (persons) connected.

Sedges are one of the most widely used and yet least studied elements of the Amazonian pharmacopeia. The relationship between several western Amazonian societies and domesticated sedges (Cyperaceae) has long intrigued travelers, missionaries, anthropologists, and ethnobotanists (Bennett 1992; Caballero-Serrano et al. 2019; Ferrero 1966; Giovannini 2015; Lewis et al. 1987; Luziatelli et al. 2010; Milliken et al. 1999; Shepard 1998; Tessmann 1930; Valadeau et al. 2010; Vickers 1976; Weiss 1969). Called piri-piri in local Amazonian Spanish and priprioca in local Amazonian Portuguese (Almeida 2010), sedges have been domesticated by native groups in Western Amazonia for non-dietary reasons (Lewis et al. 1987; Milliken et al. 1999; Plowman et al. 1990; Tournon et al. 1998). In many indigenous Amazonian groups the domestication process is entangled with the mythical origins of these plants (Cipolletti 1988; Rojas 1997, 2014; Tournon et al. 1998). Cyperus. species have been used medicinally to inhibit or stimulate women's fertility or induce abortion, as well as against snakebite, migraine headache, fever, cuts, diarrhea, vomiting, hemorrhages during childbirth, and others. (Lewis et al. 1987; Milliken et al. 1999;
Shepard 1998; Valadeau et al. 2010). They also act to restore harmonious relations within the realm of human society and protect people against the intentional actions of other humans and non-humans (Caballero-Serrano et al. 2019; Cipolletti 1988; Shepard 1998; Tournon et al. 1998).

The Cyperaceae are a monocotyledonous graminoid group of flowering plants. The Cyperaceae family accounts for 27 genera and 230 different species in Peruvian Amazonia (Vasquez and Rojas 2016). The Flora of Peru registered 30 Cyperus species distributed in Peruvian Amazonia. The inflorescences and flowers of Cyperus spp. are crucial to their botanical identification, although on occasions vegetative characteristics are used too (Tucker 1983). In domesticated sedges, inflorescences are often aborted, underdeveloped, or malformed by a fungus (Plowman et al. 1990; Stovall and Clay 1988; Tournon et al. 1998), which not only poses a challenge for their identification but also means that Cyperus spp. gain more morphological similarity.

In their local systems of classification, Western Amazonian groups usually recognize a greater number of folk species within the folk genus ibenki (Ashaninka), ivenkiki (Matsigenka) huaste (Shipibo-Conibo), and nuni (Secoya), than a corresponding number of Cyperus spp. occurring in a given region (Cipoletti 1988; Shepard 1998; Tournon et al. 1998). Western Amazonians can be considered splitters in respect to domesticated sedges (Berlin 1992). This phenomenon, identified in ethnosciences as over-differentiation, happens when local taxonomies recognize more species within one botanical genus or botanical family than botanical taxonomy does (Boster 1986). Does this over-identification indicate a privileged position of Cyperus among Western Amazonian societies in general, and among the Ashaninka in particular?

Until the 1990s, when phytochemical studies for the presence of secondary compounds on sedges began, it was assumed that the plants from this botanical family characteristically lacked pharmacological properties (Tournon et al. 1998). The medicinal popularity of Cyperus spp. among Western Amazonian people was linked to the presence of the fungus Balansia cyperi (Clavicipitaceae), which infested North and South American species of Cyperus (Plowman et al. 1990). The closely related 
B. cyperi and B. cyperaceum are known to produce different ergot alkaloids (Lewis and Elvin-Lewis 1990; Plowman et al. 1990; Stovall and Clay 1988). These authors observed that Cyperus spp. have mostly been applied by native groups to induce labor, as a homeostatic medicine, and as a hallucinogenic additive, which is consistent with the pharmacological action of ergot alkaloids. Moreover, the fungus occurs on rhizomes, young leaves, and aborted inflorescences, with the highest concentration found on rhizomes (Plowman et al. 1990). In the process of domestication, native Amazonians have practiced vegetative propagation of pepas (pieces of rhizome in local Amazonian Spanish), contributing to the maintenance of the parasite in the cultivated host; rhizomes are reported as prevalently used by indigenous groups (Luziatelli et al. 2010; Shepard 1998; Valadeau et al. 2010). On the basis of the use and plant parts employed, Plowman and colleagues conclude that "the uses of piripiri by native South American people have a biological basis in compounds produced by the fungus not the host plant" (1990: 453). In the obstetric use of infected Cyperus, Lewis and Elvin-Lewis saw yet another "sophisticated example of human ingenuity using empirical methodology" (1990: 133). Recent phytochemical studies on different species of Cyperus show that Cyperus rotundus, C. odoratus especially, but also $C$. prolixus, $C$. luzulae, C. diffusus, C. articulatus, which occur in Amazonia, contain allelochemicals, such as alkaloids, coumarins, flavonoids, saponins, tannins, and terpenoids, among other compounds (Babu and Savithramma 2014; Desmarchelier et al. 1996; Dhillon et al. 1993; Kilani et al. 2008; Udari 2018; VelásquezPérez and Galeano-García 2012; Zoghbi et al. 2008). These findings may shed new light on the wide medicinal use of Cyperus spp. in Western Amazonia. However, the diversity of uses outstretches the boundaries of what is considered "medicinal" in orthodox Western thinking (Shepard 1998).

With this study we attempt to understand the social importance of Cyperus spp. to the Ashaninka people from Western Amazonia. What can explain the over-identification and the great diversity of uses for Cyperus by the Ashaninka society, since the phytochemical properties of Cyperus and the ergot alkaloids found in the Balansia fungi do not seem to be sufficient to explain this phenomenon? In other words, what can explain the agency of ibenki for the Ashaninka people?
We propose calling our method of analysis a more-than-utility approach to ethnobotany, to investigate the social and ontological relations between the Ashaninka and this group of plants. In order to do so we 1) present the Ashaninka mythical origin of domestication of sedges; 2) examine the phenomenon of over-differentiation in connection with the cognitive system behind folk species of ibenki: groupings and naming, as well as the function of the names; 3) consider how the diversity of names is related to consensus regarding their uses; 4 ) discuss and analyze the uses within three overarching categories of causes, actions, and symptoms, which enable us to answer the question of whether the Ashaninka case supports the phytochemical action of Cyperus and Cyperus-fungus association; 5) address the issue of ibenki exchange and the patterns behind their circulation among the Ashaninka commnities.

\section{Methods}

\section{Study Group and Data Collection}

The Ashaninka belong to the Arawak linguistic family and number over 112,000 members in Peru (BDPI 2020). In Peru they inhabit the tributaries of the Upper Ucayali River, particularly the valleys of the Apurímac, Ene, Perené, Pangoa, and Tambo, as well as the Pichis and Pachitea rivers and the interfluvial area of the Gran Pajonal, in the region referred to as Selva Central (Rojas 1997; Varese 2006; Veber 2003). Ashaninka people from the study area live in comunidades nativa (native communities), formally recognized by the Ley de Comunidades Nativas no. 20656 (1974).

We worked in Ashaninka communities along the Tambo River, affiliated to the regional organization CART (Central Asháninka del Río Tambo). The Ashaninka communities that collaborated with this research were: Oviri, Anapate, Poyeni with its three hamlets: Shikapaja, Savareni, and Selva Verde, then Vista Alegre, Capitiri, Charauaja, Shevoja, Marankiari, and Chembo (Fig. 1). Overall, these twelve communities have legal rights over 81,000 ha of tropical highland forest in Peruvian central Amazonia, with between 1000 and 16,000 ha assigned to each community (SICNA 2016). The number of inhabitants in each community ranges between 80 and 500. The information was collected by Joanna Sosnowska and Monika 


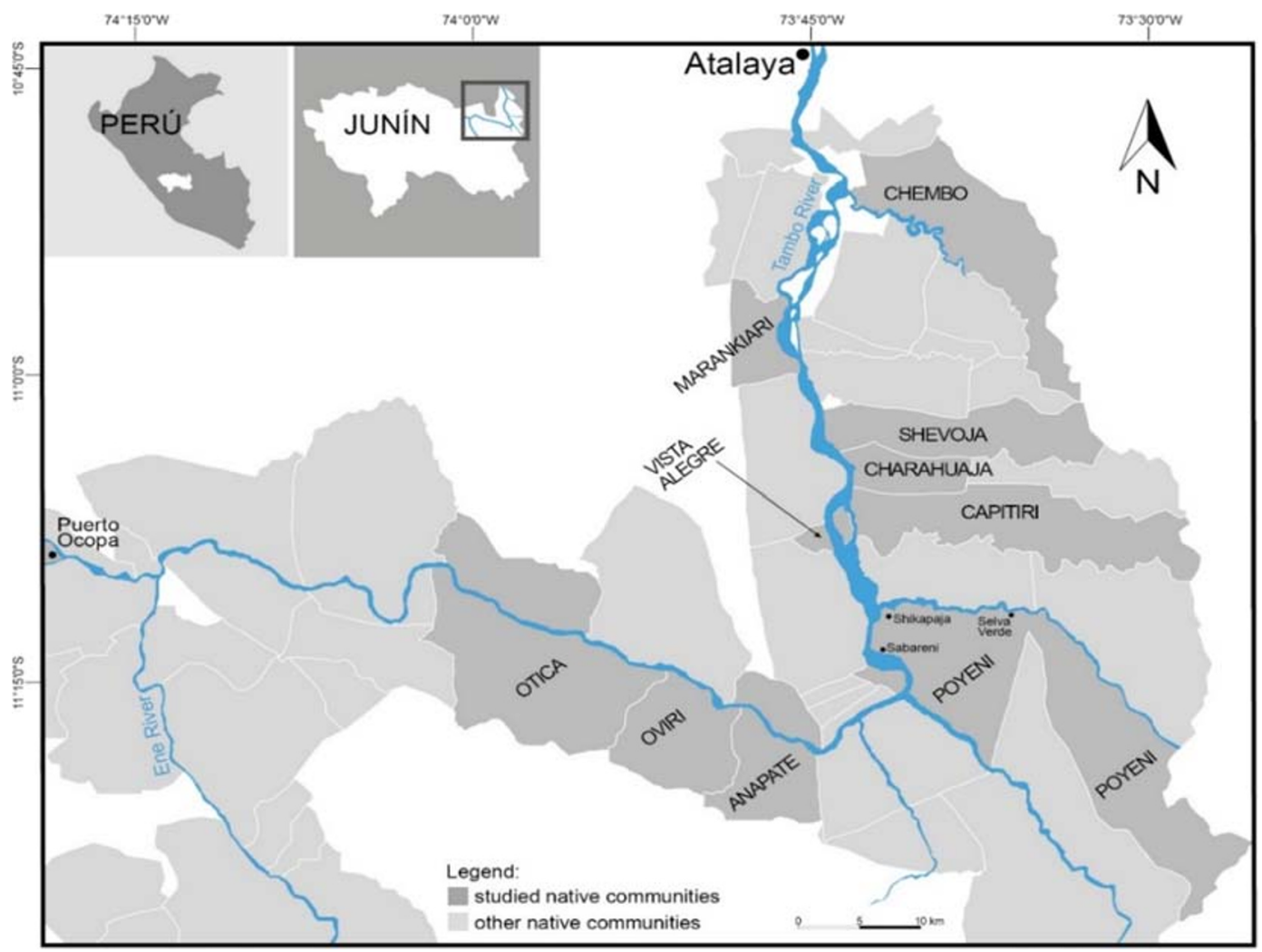

Fig. 1. The map of the Ashaninka communities along the Tambo River, with marked communities showing where the research was conducted. Legend: Otica participated in the general study, but no home gardens were surveyed in this community

Kujawska during four field stays in 2016, 2017, 2018, and 2019. Medicinal plants were cataloged in 66 home gardens, but the data on Cyperus come from 58 of the 66 gardens studied. The number of plant owners does not equal the number of home gardens, as some married couples share one garden, but spouses keep their own separate ibenki. We have data from 64 persons: 53 women and 11 men. The owners of ibenki were asked for plant names (in Ashaninka), their uses, forms and the sites from which they are procured (Fig. 2). A standard ethnobotanical technique-cataloging of plants in home gardens-was supplemented by open-ended interviews and conversations with lay Ashaninka and experts in ethnomedicine.

Herbarium specimens were collected randomly in the case of Cyperus species, due to their abundance in home gardens. Ten herbarium specimens of domesticated Cyperus spp. and one of wild growing Cyperus were collected. The specimens were processed according to the conventional parameters for herborization and conservation, and deposited in the Herbario de San Marcos del Museo de Historia Natural (USM) in Lima, with duplicates in the Herbarium of the Institute of Botany of the Polish Academy of Sciences in Krakow (KRAM). Permission for conducting the research and collecting herbarium specimens was granted by SERFOR, N ${ }^{\circ}$ 252-2017-SERFOR/DGGSPFFS. Ashaninka people signed an informed consent form.

\section{Data ANALYSIS}

Here we focus exclusively on plants from the Cyperus genus. Our analysis is largely based on the 255 exemplars collected during fieldwork. We define an exemplar as a specific recorded ibenki (name, information on use, forms and places of obtaining, photography and/or voucher specimen) in a particular garden $(N=58)$, belonging to a particular 

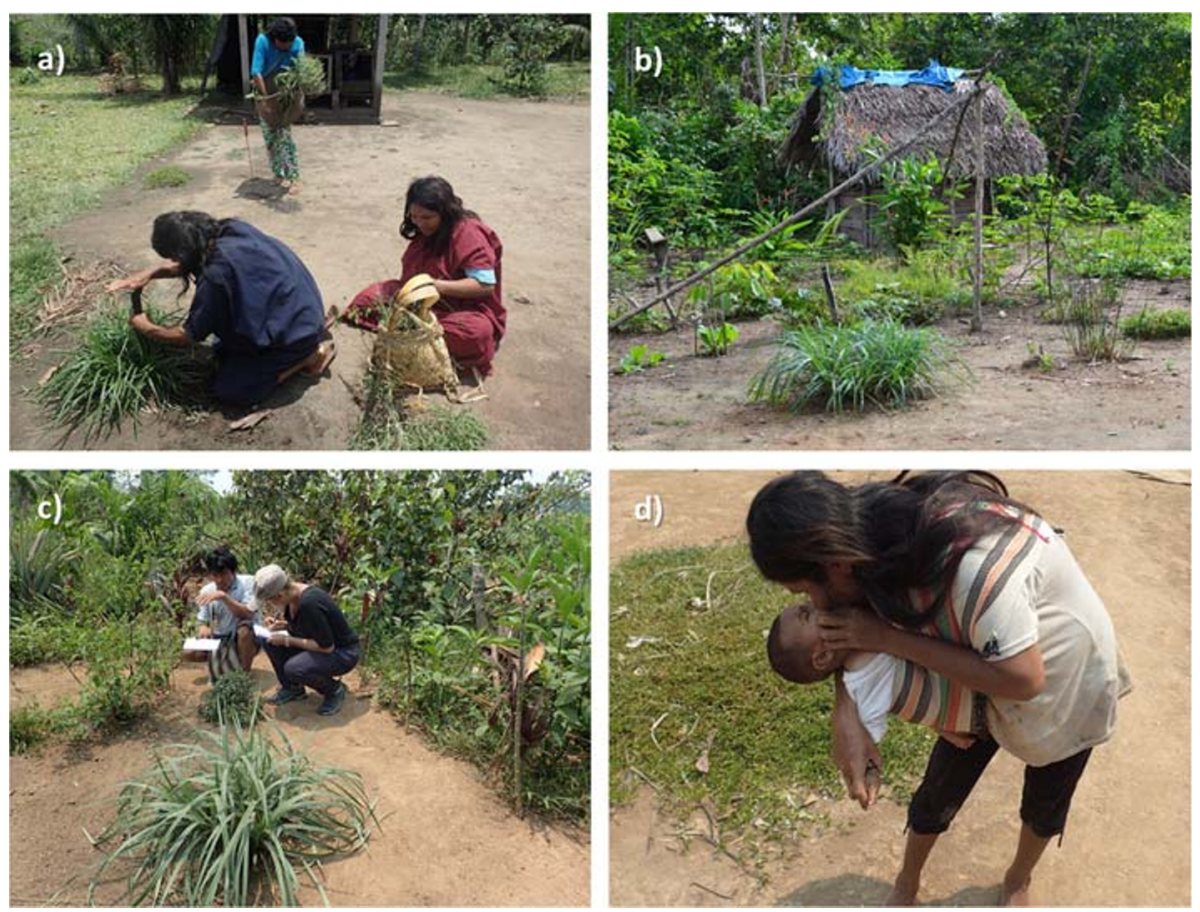

Fig. 2. Ashaninka people and their ibenki (Cyperus spp.). a), b), c) collecting information in Ashaninka home gardens along the Tambo River; d) Ashaninka woman showing the way she passes juice released through chewing ibenki's rhizome to her baby

person $(N=64)$, the botanical identification for which was established through the collection of a photograph or voucher specimen.

The story of the mythical origin of ibenki (Cyperus) has been recorded and considered in the analysis, as the central element to interpret the ontological position of these plants. We analyze Cyperus spp. from the perspective of folk taxa (including folk genera and folk species), that is, as classes of plants distinguished by Ashaninka people and endowed with separate Ashaninka names. As "nomenclature is often a nearly perfect guide to folk taxonomic structure" (Berlin et al. 1974: 27), our scrutiny of plant classification and plant nomenclature are interconnected. As such, our cognitive analysis of plant groupings and nomenclature has been combined with the semantic analysis of names and medicinal uses found behind them.

Venn diagrams were prepared and used to present the structure of grouping ibenki in the home gardens. The Ashaninka plant names were translated into Spanish with the help of native interpreters. We draw on Berlin's et al. (1974) approach and tools to analyze the nomenclature and classification of ibenki, without assuming authors' universalist position. Medicinal uses were divided into three major groups, overarching categories, based on cause, action, and symptom. In this analysis, we measured the proportion of use reports for each category (UR, defined as a specific use of a given folk species, which was mentioned by a given interlocutor). In the description of uses, we attempted to present our interlocutors' message accurately.

We conducted consensus analysis based on number of mentions of folk species and corresponding uses. For this, we used Trotter and Logan's (1986) consensus index $\left[\left(\frac{N m-N u}{N m-1}\right)\right]$ where $\mathrm{Nm}$ refers to the number of mentions, and $\mathrm{Nu}$ to the number of uses. In our case, and taking into account folk species, we aimed to search for agreement on each folk taxon (and a corresponding name), in order to establish the degree of consensus between name (folk species) and use.

While this formula gives us information about the name-use consensus, it reveals little about the name-use consensus distributed between the communities. In order to do this, 
we slightly modified the Trotter and Logan index by adding a component that considers the distribution of names across the communities (we refer to as "overall community consensus on use"), as in the following formula $\left(\frac{N m-N u}{N m-1}\right) x\left(\frac{N c}{N t c}\right)$. The aggregated component contemplates the relationship between the number of communities $(\mathrm{Nc})$ where a name was mentioned and the total number of communities (Ntc) where the fieldwork was done $(N=12)$. That is, when the same name is used consistently among a greater number of communities (Ntc), the greater its spatial circulation. A relatively high score, close to 1.0 , would reveal a highly communicative and transmissive value for a given specific ibenki. Our analyses only included names (specific ibenki) mentioned by at least three study participants. We may state that a folk species of $i b e n k i$ is efficiently circulating among communities, when the same name is used in a greater number of communities under the same type of use (has high Overall Community Consensus on Use).

We complemented our research on the relationship between the Ashaninka people and domesticated Cyperus spp. with an analysis of the manner and places from which propagules of ibenki were obtained by each of our collaborators.

\section{Results and Discussion}

\section{Domesticated CYPERUS (IBENKI) - Their \\ Place in Ashaninka Agricultural and Cosmological Order}

Like other Arawak groups, the Ashaninka have a long history of practicing horticulture, probably developed across millennia (Heckenberger 2005; Hill and Santos-Granero 2002). All live somewhere in a continuum between self-subsistence and participation in a market economy, though where on that continuum varies between and within communities, and over time (Peralta and Kainer 2008). Every Ashaninka family has at least one swidden field where principal domesticated plants and cash crops are tended. The home gardens (Span. huerto, Ash. nobanki bemento "mi huerto"), where medicinal plants grow, are most often located in the immediate proximity of the principal house of each family. The home garden area is marked by the careful and continuous elimination of weeds, sometimes to the level of bare soil; hence the cultivated space is distinguished from the naturally growing vegetation (Ash. inchatoshi). A similar pattern of marking home gardens was observed among the Matsiguenka—another Arawak-speaking group from Peru (Wezel and Ohl 2005). Cyperus are between 40 and $100 \mathrm{~cm}$ tall and grow in bush-like formations (see Tournon et al. 1998). Ibenki are planted close to the entrance to the home gardens or scattered around the home gardens (Perrault-Archambault and Coomes 2008; Valadeau et al. 2010). Santos-Granero (2012: 183) sees Arawakan gardens as a product of moral and ecological engagement-composite sites that epitomize "multiple social relations."

According to Tournon et al. (1998), a long process of Cyperus domestication has disappeared from ethnic memory and has given rise to a series of mythical origins. We assume, however, that the process of domestication cannot be separated from the mythical history. In the Ashaninka story about the origin of ibenki, it was a sankori ant (cf. leaf cutter ant, Atta spp.), who gave an Ashaninka man his first ibenki to help him weed his agriculture field more efficiently.

One time lived Sankori-coqui [in Spanish] as a person, as people. The Ashaninka lived scattered across the forest. Each family lived in a house, which was 3-4 hours away from the next. One man lived in his house and had his swidden field. Every day he used to go to his field to weed it with a machete, but he could make little progress. His son accompanied him from time to time, but sometimes he would go to the forest to collect fruit, other plants, or to hunt animals. When the man was alone in his field, Sankori would show up and say, 'I see you work every day in your field, but you make little progress.' 'Well', said Sankori, 'Tomorrow I will come to help you.' Sankori blew the swidden field with his piri-piri, before the man came. When the man came to his field, Sankori also arrived with his family, and they helped him to weed the field with a machete. They slashed the weeds quickly. Sankori and his family had small machetes-they weren't real machetes, but Sankori's teeth. The man also worked and 
slashed weeds quickly that time. When they finished, the man invited Sankori and his family to his house to have masato [cassava fermented drink] — they treated each other as brothers-in-law. They drank masato and the man asked, 'Why have we advanced so quickly today? We have weeded out a lot! You, Sankori, you must have something.' Sankori, as he had already drunk masato, showed his piri-piri to the man and gave it to him. But, he said, 'It's a secret. You can't show it to anyone. It is only for you. Sow it!'And the man remained with piri-piri for slashing the field. ['Hence', says Irineo, who told the story, 'it's our routine, our way of thinking until now'].

Nowadays, the ibenki used in agriculture to weed and burn the swidden field are rare. Elderly people remember that their grandparents used to have ibenki, which they would blow over the surface that was to be burned, and a single man could control the burning, supported by the ibenki help-action. In the agricultural domain, kaniribenki ("herb of cassava") is still used, blown on cassava cuttings to enhance their growth (Table 1).

For the Ashaninka, as for other Amazonian groups, animals and plants are endowed with intentionality, and emotional and communicative capacities (Daly 2015; Descola 1996; Santos-Granero 2012). The Ashaninka perceive their relationship with animals, plants, and generally non-humans in social terms. Cultivated, and especially domesticated plants are plant-persons (Daly 2015; Rojas 1997). According to the Ashaninka myth, Sankori, who offers ibenki, is a potential affine-brother-inlaw to the Ashaninka man. As with other Amazonian groups, in Ashaninka kinship, a husband or wife (affine) is an outsider, and it is during the prolonged convivial coexistence, sharing intimacy and commensality that the affine progressively becomes kin (see Belaunde 2001; Rival 2002; SantosGranero 2012; Seeger et al. 1979). Hence, the Ashaninka and ibenki are actively involved in the mutual production of kinship, a point we will return to. Here, we want to accept that domesticated Cyperus are persons-plants, kin, and important allies to Ashaninka people, whom the Ashaninka socialize with during the encounters in the home gardens and through the ingestion of ibenki.

\section{IbENKI - THE PATTERnS BEHIND THEIR GROUP- ING AND NAMING}

Within the folk genus ibenki a great diversity of Ashaninka specific names are to be found. Each specific ibenki is endowed not only with a name, but with discrete properties and/or uses. Therefore, each specific ibenki is considered a separate folk species (ethnospecies), rather than an example of polysemy, where different names are applied to the same botanical taxon. We identified a one-to-one correspondence between the botanical genus Cyperus and the folk generic taxon ibenki (Fig. 3). Within this folk genus, we find two monotypic names: ibenki and shiobana, which can be translated as "an herb." Shiobanas are considered a sub-group within ibenki. People use the generic name ibenki and shiobana when they do not know or do not want to reveal the proper name of their Cyperus plants. We recorded 28 different exemplars under the name ibenki and 23 different exemplars under the name shiobana (Table 1).

Thirty species in the Cyperus genus have been identified in Peruvian Amazonia (Ayala 2003). In our study we identified four species-Cyperus odoratus L., Cyperus laxus Lam., Cyperus manimae Kunth, Cyperus prolixus Kunth-and unspecified Cyperus spp., corresponding to 86 descriptive names, which we treat here as 86 different folk species of ibenki (We counted lexemic variations as one name, e.g., janabenki/janaribenki "herb of a fish"). Even though we did not collect all the Cyperus species used by the Ashaninka, we can clearly observe, from the botanical perspective, an over-differentiation. Strikingly, from the 86 folk species recorded, 49 (57\%) were mentioned by a single person, which may indicate little sharing, and a family-based circuit in knowing and naming them. One case of sub-differentiation was observed under the name of shijarontsibenki ("herb of diarrhea") that corresponded to two biological species (C. prolixus and C. laxus).

Names of specific ibenki are secondary lexemes composed of a semantically productive constituent and a generic suffix (i)benki (e.g., avotsibenki: avotsi - path, (i)benki - generic suffix,"a herb"). The analysis of these secondary lexemes shows that specific names are not based on color, shape, habitat, or morphological cues, as observed in many folk systems (Berlin 1992). Names, such as cocobenki ("herb of coconut") or kanaribenki ("herb of cassava") may be misleading. They do not indicate the 
Table 1. Ibenki folk species recorded in Ashaninka home gardens in Peruvian Amazonia

\begin{tabular}{|c|c|c|c|c|c|}
\hline $\begin{array}{l}\text { Ashaninka name/ } \\
\text { Ashaninka folk } \\
\text { species }\end{array}$ & $\begin{array}{l}\text { Spanish and English } \\
\text { translation of } \\
\text { Ashaninka name }\end{array}$ & $\begin{array}{l}\text { Botanical } \\
\text { taxon / no. of } \\
\text { collection }\end{array}$ & Category of Use & Use & $\begin{array}{l}\begin{array}{l}\text { No. of } \\
\text { mentions }\end{array}\end{array}$ \\
\hline aimentantsipini & & Cyperus sp. & Partners' infidelity & $\begin{array}{l}\text { Chest hoarseness and a } \\
\text { cough that affects a } \\
\text { baby when one of the } \\
\text { parents has had } \\
\text { extramarital sexual } \\
\text { relations }\end{array}$ & 1 \\
\hline amokorojantsibenki & & Cyperus sp. & $\begin{array}{l}\text { Digestive } \\
\text { problems }\end{array}$ & $\begin{array}{l}\text { Used to help the } \\
\text { digestion; when one } \\
\text { eats food that hasn't } \\
\text { been well cooked }\end{array}$ & 1 \\
\hline ampajiyantsibenki & $\begin{array}{l}\text { Span. hierba del } \\
\text { insomnio / "niño que } \\
\text { está afligido", Eng. } \\
\text { herb of insomnia / } \\
\text { "child who is } \\
\text { afflicted" }\end{array}$ & Cyperus sp. & Spirits & $\begin{array}{l}\text { Used when a child is } \\
\text { anxious, doesn't want } \\
\text { to sleep, due to parents } \\
\text { travel with him/her to } \\
\text { the forest or to the } \\
\text { garden }\end{array}$ & 1 \\
\hline $\begin{array}{l}\text { ampatsibenki, } \\
\text { ampetsibenki }\end{array}$ & $\begin{array}{l}\text { Span. hierba de los } \\
\text { fantasmas, de las } \\
\text { almas muertas, Eng. } \\
\text { herb of spirits, of } \\
\text { dead souls }\end{array}$ & Cyperus sp. & Spirits & $\begin{array}{l}\text { Used when someone dies } \\
\text { in the household, in } \\
\text { order to avoid voices of } \\
\text { the dead. It prevents } \\
\text { the spirit of the dead } \\
\text { from returning home } \\
\text { and bothering } \\
\text { members of the family. }\end{array}$ & 3 \\
\hline aronibenki & $\begin{array}{l}\text { Span. hierba de la } \\
\text { caracara de vientre } \\
\text { blanco, Eng. herb of } \\
\text { an aroni bird }\end{array}$ & Cyperus sp. & Spirits & $\begin{array}{l}\text { Used when a person has } \\
\text { visions }\end{array}$ & 1 \\
\hline asabakochiariakoki & $\begin{array}{l}\text { Span. echar a manos, } \\
\text { Eng. throw on hands }\end{array}$ & Cyperus sp. & Expert medicine & $\begin{array}{l}\text { Used in initiation for } \\
\text { those who heal with } \\
\text { mini-saunas/- } \\
\text { vaporation. It helps to } \\
\text { see the cause of an } \\
\text { illness. }\end{array}$ & 1 \\
\hline $\begin{array}{l}\text { atsanantsibenki, } \\
\text { atsanabenki }\end{array}$ & $\begin{array}{l}\text { Span. hierba del } \\
\text { egoismo, engaño, } \\
\text { relacion sexual fuera } \\
\text { de la pareja, Eng. } \\
\text { herb of of selfishness, } \\
\text { deception, } \\
\text { extramarital sexual } \\
\text { intercourse }\end{array}$ & Cyperus sp. & $\begin{array}{l}\text { Partners' } \\
\text { infidelity, } \\
\text { Spirits }\end{array}$ & $\begin{array}{l}\text { Chest hoarseness and a } \\
\text { cough that affects a } \\
\text { baby when one of the } \\
\text { parents has had } \\
\text { extramarital sexual } \\
\text { relations; when one has } \\
\text { visions }\end{array}$ & 5 \\
\hline $\begin{array}{l}\text { atsorentsibenki, } \\
\text { atsarentsibenki }\end{array}$ & $\begin{array}{l}\text { Span. hierba dilatora, } \\
\text { Eng. dilator herb }\end{array}$ & Cyperus sp. & $\begin{array}{l}\text { Food } \\
\text { proscriptions, } \\
\text { Childbirth }\end{array}$ & $\begin{array}{l}\text { Used to accelerate labor. } \\
\text { When a woman eats } \\
\text { certain game or fruit it } \\
\text { can affect the fetus } \\
\text { (cutipar) and thus the } \\
\text { parturient woman has } \\
\text { problems when giving } \\
\text { birth }\end{array}$ & 5 \\
\hline
\end{tabular}


Table 1. (Continued).

\begin{tabular}{|c|c|c|c|c|c|}
\hline $\begin{array}{l}\text { Ashaninka } \\
\text { name/Ashaninka } \\
\text { folk species }\end{array}$ & $\begin{array}{l}\text { Spanish and English } \\
\text { translation of } \\
\text { Ashaninka name }\end{array}$ & $\begin{array}{l}\text { Botanical } \\
\quad \operatorname{taxon} / \text { no. } \\
\text { of } \\
\text { collection }\end{array}$ & Category of Use & Use & No. of \\
\hline abotsibenki & $\begin{array}{l}\text { Span. hierba del } \\
\text { camino, Span. herb } \\
\text { of a path }\end{array}$ & Cyperus sp. & Spirits & $\begin{array}{l}\text { Given to a newborn so } \\
\text { that the devil does not } \\
\text { harm him/her, } \\
\text { preventing the baby } \\
\text { from being cutipado by } \\
\text { any animal or tree } \\
\text { [Span. palo]. The } \\
\text { baby's spirit always } \\
\text { accompanies his father } \\
\text { when he goes to the } \\
\text { forest - this ibenki ac- } \\
\text { companies the father } \\
\text { apart from protecting } \\
\text { the baby. }\end{array}$ & 1 \\
\hline $\begin{array}{c}\text { Bairontsibenki, } \\
\text { obairontsiki }\end{array}$ & $\begin{array}{l}\text { Span. hierba del } \\
\text { nombre; Eng. herb of } \\
\text { a name }\end{array}$ & Cyperus sp. & $\begin{array}{l}\text { Reproductive } \\
\text { health }\end{array}$ & $\begin{array}{l}\text { Used to improve a } \\
\text { woman's fertility, helps } \\
\text { her to get pregnant }\end{array}$ & 3 \\
\hline batsarobenki & $\begin{array}{l}\text { Span. hierba de la } \\
\text { herida, Eng. herb of a } \\
\text { wound }\end{array}$ & Cyperus sp. & Skin & Wounds & 1 \\
\hline charabaibenki & $\begin{array}{l}\text { Span. hierba del } \\
\text { zúngaro, Eng. herb of } \\
\text { a zúngaro fish }\end{array}$ & Cyperus sp. & Fishing & $\begin{array}{l}\text { Uses by men to have luck } \\
\text { when fishing zúngaro }\end{array}$ & 1 \\
\hline charibenki & $\begin{array}{l}\text { Span. hierba de la } \\
\text { cortadura, Eng. herb } \\
\text { of a cut }\end{array}$ & Cyperus sp. & Cut & Used for any type of cuts & 1 \\
\hline charijabenki & $\begin{array}{l}\text { Span. hierba de malla } \\
\text { /tarrafa de pescar, } \\
\text { Eng. herb of a fishing } \\
\text { net }\end{array}$ & $\begin{array}{l}\text { Cyperus sp. } \\
\text { [MK 404], } \\
\text { Cyperus sp. }\end{array}$ & $\begin{array}{l}\text { Fishing, Food } \\
\text { proscriptions }\end{array}$ & $\begin{array}{l}\text { Used when fishing net } \\
\text { doesn't catch fish, } \\
\text { when man doesn't } \\
\text { have luck at fishing, } \\
\text { when a wife or } \\
\text { daughter eats fish } \\
\text { during her } \\
\text { menstruation, so that a } \\
\text { man loses his good luck } \\
\text { at fishing; a pregnant } \\
\text { woman may be } \\
\text { cutipada by a fishing } \\
\text { net and has pain and } \\
\text { cold during labor. }\end{array}$ & 7 \\
\hline cocobenki & $\begin{array}{l}\text { Span. hierba del coco, } \\
\text { Eng. herb of a coco } \\
\text { fruit }\end{array}$ & Cyperus sp. & $\begin{array}{l}\text { Food } \\
\quad \text { proscriptions }\end{array}$ & $\begin{array}{l}\text { Used when the woman } \\
\text { has labor pains because } \\
\text { she has been eating } \\
\text { coco fruit in excess }\end{array}$ & 1 \\
\hline eiro abantatsi & $\begin{array}{l}\text { Span. "no tengo hijos", } \\
\text { Eng." I don't have } \\
\text { children." }\end{array}$ & Cyperus sp. & $\begin{array}{l}\text { Reproductive } \\
\text { health }\end{array}$ & $\begin{array}{l}\text { Used as a contraceptive, } \\
\text { when a woman doesn't } \\
\text { want to get pregnant }\end{array}$ & 1 \\
\hline $\begin{array}{l}\text { eiroo tonkantatsi } \\
\text { tonkamentotsi }\end{array}$ & $\begin{array}{l}\text { Span. "respondo con la } \\
\text { escopeta", Eng. "I am } \\
\text { responding with a } \\
\text { shotgun." }\end{array}$ & Cyperus sp. & Violence & $\begin{array}{l}\text { Applied on shotguns and } \\
\text { used by a man who } \\
\text { wants to aim at } \\
\text { enemies }\end{array}$ & 1 \\
\hline
\end{tabular}


Table 1. (Continued).

\begin{tabular}{|c|c|c|c|c|c|}
\hline $\begin{array}{l}\text { Ashaninka } \\
\text { name/Ashaninka } \\
\text { folk species }\end{array}$ & $\begin{array}{l}\text { Spanish and English } \\
\text { translation of } \\
\text { Ashaninka name }\end{array}$ & $\begin{array}{l}\text { Botanical } \\
\quad \text { taxon / no. } \\
\text { of } \\
\text { collection }\end{array}$ & Category of Use & Use & No. of \\
\hline emokibenki & $\begin{array}{l}\text { Span. hierba del suri; } \\
\text { Eng. herb of suri- } \\
\text { palm weevil }\end{array}$ & Cyperus sp. & $\begin{array}{l}\text { Food } \\
\quad \text { proscriptions }\end{array}$ & $\begin{array}{l}\text { Used when a woman has } \\
\text { labor pains and } \\
\text { difficulties with } \\
\text { delivery. She has been } \\
\text { cutipada with suri }\end{array}$ & 1 \\
\hline iamabenki & $\begin{array}{l}\text { Span. hierba pulsera, } \\
\text { Eng. bracelet herb }\end{array}$ & Cyperus sp. & $\begin{array}{l}\text { Prophylaxis, } \\
\text { Spirits }\end{array}$ & $\begin{array}{l}\text { Used as a protection, in } \\
\text { order that one doesn't } \\
\text { get ill }\end{array}$ & 1 \\
\hline ibatsabenki & $\begin{array}{l}\text { Span. hierba de la carne, } \\
\text { Eng. herb of meat }\end{array}$ & Cyperus sp. & Spirits & $\begin{array}{l}\text { Used when one has } \\
\text { visions, talks to the } \\
\text { devil, this produces } \\
\text { vomits and diarrhea }\end{array}$ & 1 \\
\hline ibenki & $\begin{array}{c}\text { Span. hierba [a generic } \\
\text { name for Cyperus] }\end{array}$ & Cyperus sp. & $\begin{array}{l}\text { Childbirth, Bites, } \\
\text { Digestive } \\
\text { problems, } \\
\text { Expert } \\
\text { medicine, Food } \\
\text { proscriptions, } \\
\text { Hair, Hunting, } \\
\text { Parent-child } \\
\text { relations, Part- } \\
\text { ners' infidelity, } \\
\text { Skin, Spirits, } \\
\text { Witchcraft }\end{array}$ & $\begin{array}{l}\text { Used to accelerate labor; } \\
\text { snake bite; diarrhea, to } \\
\text { enable one to become } \\
\text { an expert in mini } \\
\text { sauna/vaporation; } \\
\text { when the husband } \\
\text { cannot hunt anymore } \\
\text { because his wife ate } \\
\text { game meat during her } \\
\text { menstruation; when } \\
\text { parents eat a bird, this } \\
\text { can affect the baby, and } \\
\text { the baby may emit a } \\
\text { sound identical to this } \\
\text { bird; to enhance hair } \\
\text { growth; extramarital } \\
\text { sexual relations of one } \\
\text { of the spouses, a bug } \\
\text { penetrates his/her body } \\
\text { transmitted by the } \\
\text { other person - a } \\
\text { symptom is a pulsing } \\
\text { navel; mal aire; } \\
\text { aphthae; sorcery }\end{array}$ & 28 \\
\hline iishintsibenki & $\begin{array}{l}\text { Span. hierba del cabello, } \\
\text { Eng. herb of hair }\end{array}$ & Cyperus sp. & Hair & $\begin{array}{l}\text { Used to enhance a } \\
\text { woman's hair growth }\end{array}$ & 3 \\
\hline $\begin{array}{l}\text { irajantsibenki, } \\
\text { irantsibenki }\end{array}$ & $\begin{array}{l}\text { Span. hierba de la sangre } \\
\text { (ira), Eng. herb of } \\
\text { blood }\end{array}$ & Cyperus sp. & $\begin{array}{l}\text { Childbirth, Food } \\
\text { proscriptions, } \\
\text { Reproductive } \\
\text { health }\end{array}$ & $\begin{array}{l}\text { Used to prevent the } \\
\text { hemorrhage during } \\
\text { labor; when a woman } \\
\text { has excessive bleeding } \\
\text { during period; when a } \\
\text { woman eats fish or } \\
\text { game meat during } \\
\text { menstruation - then } \\
\text { her husband or her fa- } \\
\text { ther cannot hunt nor } \\
\text { fish any more }\end{array}$ & 14 \\
\hline
\end{tabular}


Table 1. (Continued).

\begin{tabular}{lccccc}
\hline \hline $\begin{array}{l}\text { Ashaninka } \\
\text { name/Ashaninka } \\
\text { folk species }\end{array}$ & $\begin{array}{c}\text { Spanish and English } \\
\text { translation of } \\
\text { Ashaninka name }\end{array}$ & $\begin{array}{c}\text { Botanical } \\
\text { taxon / no. } \\
\text { of } \\
\text { collection }\end{array}$ & Category of Use & Use & No. of \\
\hline
\end{tabular}

itobenki Span. hierba de cabeza,

Cyperus sp. Spirits

itonkibenki

Span. hierba del hueso,

Eng. herb of a bone

Cyperus sp.

Used by a pregnant woman 1

janabenki

Span. hierba del
pescado, Eng. herb of
a fish

Cyperus sp.

Digestive

janekibenki

Span. hierba del niño,

Cyperus sp.

Eng. herb of a child

jempabenki

Span. hierba del

adormecimiento,

Eng. herb of

numbness

kamarankantsibenki

Span. hierba de vomitar, Cyperus sp.

Eng. herb of vomiting

kamaribenki

Span. hierba del diablo, Cyperus del mal, Eng. herb of odoratus $\mathrm{L}$. the devil

[JS 130],

Cyperus sp.

kamarobenki
Span. hierba de mujer Cyperus sp. Spirits, diablo, Eng. herb of a she-devil

Used for headache

produced by an

encounter with the

devil. One walks in the

forest alone, meets and

talks to an apparently

known person, but this

is the devil. One may

die from this

Food proscription

encounter.

who is tempted by

different types of food

which she should avoid

during pregnancy problems

2

Stomach ache,

indigestion produced

by eating raw or

semi-raw food

Child rearing

Used for lack of appetite among children, when they don't want to eat cassava

Numbness of legs

Symptom

Digestive

Used when one vomits problems

Spirits

mal aire, when one meets with kamari - this produces headache, visions produced by encounters with beings of the forest

When a person dies, $\quad 7$ his/her cassava also dies - although it looks healthy from the outside. It is used to prevent cassava rotting; used to protect one's own garden with cassava in the situation when a dead person or someone from his/her household used to pass it every day; used to heal a shotgun when one doesn't have luck in hunting 
Table 1. (Continued).

\begin{tabular}{|c|c|c|c|c|c|}
\hline $\begin{array}{l}\text { Ashaninka } \\
\text { name/Ashaninka } \\
\text { folk species }\end{array}$ & $\begin{array}{l}\text { Spanish and English } \\
\text { translation of } \\
\text { Ashaninka name }\end{array}$ & $\begin{array}{l}\text { Botanical } \\
\quad \text { taxon / no. } \\
\text { of } \\
\text { collection }\end{array}$ & Category of Use & Use & No. of \\
\hline kamatsiribenki & $\begin{array}{l}\text { Span. hierba del } \\
\text { muerto, Eng. herb of } \\
\text { the dead }\end{array}$ & Cyperus sp. & Spirits & $\begin{array}{l}\text { Used for lack of appetite - } \\
\text { related to the death of a } \\
\text { family member }\end{array}$ & 1 \\
\hline kaneikibenki & $\begin{array}{l}\text { Span. hierba de la } \\
\text { hormiga rallada, Eng. } \\
\text { herb of a kaneiki ant }\end{array}$ & Cyperus sp. & Spirits & $\begin{array}{l}\text { Used when an ant kaneiki } \\
\text { bewitches an adult or a } \\
\text { child. The symptoms } \\
\text { are wounds or pimples } \\
\text { on the skin }\end{array}$ & 1 \\
\hline kaniribenki & $\begin{array}{l}\text { Span. hierba de la yuca, } \\
\text { Eng. herb of cassava }\end{array}$ & Cyperus sp. & $\begin{array}{l}\text { Spirits, } \\
\text { Horticulture, } \\
\text { Parents-child } \\
\text { relations }\end{array}$ & $\begin{array}{l}\text { Used to enhance the } \\
\text { growth of cassava; } \\
\text { when a person dies in } \\
\text { the family, used to } \\
\text { protect her/his cassava } \\
\text { so it won't die too; } \\
\text { used when a child suf- } \\
\text { fers from lack of appe- } \\
\text { tite because she/he has } \\
\text { inhaled the smell of the } \\
\text { menstruating blood of } \\
\text { his mother }\end{array}$ & 5 \\
\hline karaparitsibenki & $\begin{array}{l}\text { Span. hierba del } \\
\text { cascabél, Eng. herb of } \\
\text { a rattlesnake }\end{array}$ & Cyperus sp. & Bite & Rattlesnake bite & 1 \\
\hline katsinkashiri & $\begin{array}{l}\text { Span. frío de la luna, } \\
\text { Eng. cold of the } \\
\text { moon }\end{array}$ & Cyperus sp. & Symptom & $\begin{array}{l}\text { Used when one feels cold } \\
\text { in the feet }\end{array}$ & 1 \\
\hline kipatsibenki & $\begin{array}{l}\text { Span. hierba de la tierra, } \\
\text { Eng. herb of the soil }\end{array}$ & Cyperus sp. & Child rearing & $\begin{array}{l}\text { Used when a toddler eats } \\
\text { earth/soil }\end{array}$ & 1 \\
\hline kiriotibenki & $\begin{array}{l}\text { Span. hierba de kiroti - } \\
\text { un ave. nocturno, no } \\
\text { se la ve, Eng. herb of } \\
\text { one kind of nocturnal } \\
\text { bird, difficult to see }\end{array}$ & Cyperus sp. & Spirits & $\begin{array}{l}\text { Kiroti brings disgrace, } \\
\text { illness and heart attack. } \\
\text { Used when one feels } \\
\text { pain in the body, } \\
\text { cannot breathe }\end{array}$ & 1 \\
\hline kitotsabenki & $\begin{array}{l}\text { Span. hierba del bagre, } \\
\text { Eng. herb of a bagre } \\
\text { fish }\end{array}$ & Cyperus sp. & Fishing & Used in order to fish bagre & 1 \\
\hline koshipirinki & $\begin{array}{l}\text { Span. hierba del jergón, } \\
\text { Eng. herb of a } \\
\text { lancehead snake }\end{array}$ & $\begin{array}{l}\text { Cyperus } \\
\text { manimae } \\
\text { Kunth [MK } \\
452], \\
\text { Cyperus sp. }\end{array}$ & Bite & Bite of a lancehead snake & 2 \\
\hline manijibenki & $\begin{array}{l}\text { Span. hierba de isula - } \\
\text { hormiga grande y de } \\
\text { mordedura muy } \\
\text { dolorosa, Eng. herb } \\
\text { of a bullet ant - a big } \\
\text { ant, whose bite pro- } \\
\text { duces great pain }\end{array}$ & Cyperus sp. & Spirits & $\begin{array}{l}\text { Used against the sorcery } \\
\text { of the ant maniji. It } \\
\text { produces general body } \\
\text { pain or ache in a } \\
\text { particular part of the } \\
\text { body }\end{array}$ & 6 \\
\hline
\end{tabular}


Table 1. (Continued).

\begin{tabular}{|c|c|c|c|c|c|}
\hline $\begin{array}{l}\text { Ashaninka } \\
\text { name/Ashaninka } \\
\text { folk species }\end{array}$ & $\begin{array}{l}\text { Spanish and English } \\
\text { translation of } \\
\text { Ashaninka name }\end{array}$ & $\begin{array}{l}\text { Botanical } \\
\text { taxon / no. } \\
\text { of } \\
\text { collection }\end{array}$ & Category of Use & Use & No. of \\
\hline mapibenki & $\begin{array}{l}\text { Span. hierba de la } \\
\text { piedra, Eng. herb of a } \\
\text { stone }\end{array}$ & Cyperus sp. & Expert medicine & $\begin{array}{l}\text { Used during initiation } \\
\text { process in becoming a } \\
\text { mini sauna /vapor } \\
\text { healer }\end{array}$ & 3 \\
\hline marankebenki & $\begin{array}{l}\text { Span. hierba de la } \\
\text { víbora, Eng. herb of a } \\
\text { viper }\end{array}$ & Cyperus sp. & Spirits & $\begin{array}{l}\text { "By the time the woman } \\
\text { is pregnant and sees } \\
\text { someone who has been } \\
\text { bitten by a viper. The } \\
\text { spirit of the baby } \\
\text { [fetus] can affect and } \\
\text { swell the painful part of } \\
\text { the person that has } \\
\text { been bitten." }\end{array}$ & 1 \\
\hline mashekaribenki & $\begin{array}{l}\text { Span. hierba de falta de } \\
\text { apetito, Eng. herb of } \\
\text { lack of appetite }\end{array}$ & Cyperus sp. & $\begin{array}{l}\text { Child rearing, } \\
\text { Food } \\
\text { proscriptions }\end{array}$ & $\begin{array}{l}\text { When a child doesn't } \\
\text { want to eat cassava. } \\
\text { The cause may be that } \\
\text { the child smells the } \\
\text { menstruating blood of } \\
\text { his mother; returns } \\
\text { appetite to children } \\
\text { and adults }\end{array}$ & 6 \\
\hline masontobenki & $\begin{array}{l}\text { Span. hierba del mudo, } \\
\text { Eng. herb of a mute }\end{array}$ & Cyperus sp. & Violence & $\begin{array}{l}\text { Used so that the husband } \\
\text { does not bother the } \\
\text { wife when he returns } \\
\text { home drunk }\end{array}$ & 1 \\
\hline matsarantsibenki & $\begin{array}{l}\text { Span. hierba de la parte } \\
\text { del cuello, Eng. herb } \\
\text { of a part of neck }\end{array}$ & Cyperus sp. & Spirits & $\begin{array}{l}\text { The encounter with } \\
\text { spirits brings vomits } \\
\text { and diarrhea }\end{array}$ & 1 \\
\hline matsibenki & $\begin{array}{l}\text { Span. hierba de lo que } \\
\text { brujea, Eng. herb of } \\
\text { witchcraft }\end{array}$ & Cyperus sp. & Witchcraft & $\begin{array}{l}\text { Used when one feels being } \\
\text { bewitched; the person } \\
\text { must also follow a diet }\end{array}$ & 1 \\
\hline menkoribenki & $\begin{array}{l}\text { Span. hierba de la } \\
\text { nube/neblina, Eng. } \\
\text { herb of a cloud/fog }\end{array}$ & $\begin{array}{l}\text { Cyperus cf. } \\
\text { odoratus [JS } \\
128] \\
\text { Cyperus sp. }\end{array}$ & Spirits & $\begin{array}{l}\text { Used when an adult or a } \\
\text { child has an encounter } \\
\text { with menkori, with it } \\
\text { comes a malevolent } \\
\text { spirit }\end{array}$ & 3 \\
\hline mintsarobantsibenki & $\begin{array}{l}\text { Span. hierba del susto, } \\
\text { Eng. Herb of a fright }\end{array}$ & Cyperus sp. & Child rearing & $\begin{array}{l}\text { "When the baby is scared, } \\
\text { at night s/he makes } \\
\text { sudden movements. } \\
\text { Her/his head and body } \\
\text { are blown with the rhi- } \\
\text { zome and one says: } \\
\text { ameshiretajiri [you have } \\
\text { to come], the baby is } \\
\text { filled with her/his } \\
\text { spirit, s/he sleeps well, } \\
\text { one shouldn't wake } \\
\text { her/him up - s/he's } \\
\text { going to wake up } \\
\text { alone, then s/he's }\end{array}$ & 1 \\
\hline
\end{tabular}


Table 1. (Continued).

\begin{tabular}{|c|c|c|c|c|c|}
\hline $\begin{array}{l}\text { Ashaninka } \\
\text { name/Ashaninka } \\
\text { folk species }\end{array}$ & $\begin{array}{l}\text { Spanish and English } \\
\text { translation of } \\
\text { Ashaninka name }\end{array}$ & $\begin{array}{l}\text { Botanical } \\
\quad \text { taxon / no. } \\
\text { of } \\
\text { collection }\end{array}$ & 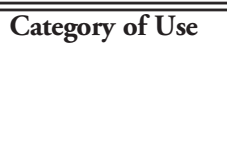 & Use & No. of \\
\hline & & & & $\begin{array}{l}\text { happy, he wants to eat } \\
\text { again." }\end{array}$ & \\
\hline mononkabenki & $\begin{array}{l}\text { Span. hierba del } \\
\text { desperdicio, Eng. } \\
\text { herb of waste }\end{array}$ & Cyperus sp. & $\begin{array}{l}\text { Child rearing, } \\
\text { Hunting }\end{array}$ & $\begin{array}{l}\text { When a child throws } \\
\text { away bones, his father } \\
\text { won't have luck in } \\
\text { hunting }\end{array}$ & 1 \\
\hline motitsibenki & $\begin{array}{l}\text { Span. hierba del } \\
\text { embarazo, Eng. herb } \\
\text { of being pregnant }\end{array}$ & Cyperus sp. & Childbirth & $\begin{array}{l}\text { Used during labor in } \\
\text { order to ease the pain }\end{array}$ & 1 \\
\hline $\begin{array}{l}\text { moitotsibenki, } \\
\text { moitontsibenki }\end{array}$ & $\begin{array}{l}\text { Span. hierba del } \\
\text { ómbligo, Eng. herb } \\
\text { of the navel }\end{array}$ & Cyperus sp. & Partner's infidelity & $\begin{array}{l}\text { The symptom is a pulsing } \\
\text { navel; the cause is } \\
\text { extramarital sexual } \\
\text { relations by one of the } \\
\text { spouses, a bug } \\
\text { penetrates the body of } \\
\text { the unfaithful partner, } \\
\text { and then the bugs are } \\
\text { transmitted to the } \\
\text { spouse and the child. }\end{array}$ & 2 \\
\hline neaasamanpentsibenki & $\begin{array}{l}\text { Span. hierba de las } \\
\text { visiones, Eng. herb of } \\
\text { visions }\end{array}$ & Cyperus sp. & Spirits & $\begin{array}{l}\text { Used when a person has } \\
\text { visions due to an } \\
\text { encounter with a } \\
\text { malevolent spirit }\end{array}$ & 1 \\
\hline neamanpiantsibenki & $\begin{array}{l}\text { Span. hierba de la visión } \\
\text { de la persona, Eng. } \\
\text { herb of a vision of a } \\
\text { person }\end{array}$ & Cyperus sp. & Spirits & $\begin{array}{l}\text { When one sees a person, } \\
\text { but not a real one. In } \\
\text { fact, it is a bad spirit } \\
\text { who enters one's body. } \\
\text { When one returns } \\
\text { home, s/he shouldn't } \\
\text { tell the family that s/he } \\
\text { has seen someone. This } \\
\text { vision causes a } \\
\text { headache, chills, } \\
\text { vomiting, because mal } \\
\text { aire is a bad spirit. If } \\
\text { the person tells other } \\
\text { people, s/he will die } \\
\text { soon. }\end{array}$ & 1 \\
\hline obayeribenki & $\begin{array}{l}\text { Span. hierba para } \\
\text { luchar, Eng. herb for } \\
\text { fighting }\end{array}$ & Cyperus sp. & Violence & $\begin{array}{l}\text { Used to intimidate an } \\
\text { enemy }\end{array}$ & 1 \\
\hline omanibenki & $\begin{array}{l}\text { Span. hierba del } \\
\text { zúngaro [another } \\
\text { kind], Eng. herb of a } \\
\text { fish zungaro }\end{array}$ & Cyperus sp. & $\begin{array}{l}\text { Food } \\
\quad \text { proscriptions }\end{array}$ & $\begin{array}{l}\text { When parents of a child } \\
\text { eat zungaroldoncella - } \\
\text { this cutipa the child } \\
\text { and gives her/him } \\
\text { diarrhea. }\end{array}$ & 1 \\
\hline otsitibenki & $\begin{array}{l}\text { Span. hierba del perro, } \\
\text { Eng. herb of a dog }\end{array}$ & Cyperus sp. & Hunting & $\begin{array}{l}\text { Used to make a dog a } \\
\text { good hunter, to }\end{array}$ & 1 \\
\hline
\end{tabular}


Table 1. (Continued).

\begin{tabular}{lccccc}
\hline \hline $\begin{array}{l}\text { Ashaninka } \\
\text { name/Ashaninka } \\
\text { folk species }\end{array}$ & $\begin{array}{c}\text { Spanish and English } \\
\text { translation of } \\
\text { Ashaninka name }\end{array}$ & $\begin{array}{c}\text { Botanical } \\
\text { taxon / no. } \\
\text { of } \\
\text { collection }\end{array}$ & Category of Use & Use & No. of \\
\hline
\end{tabular}

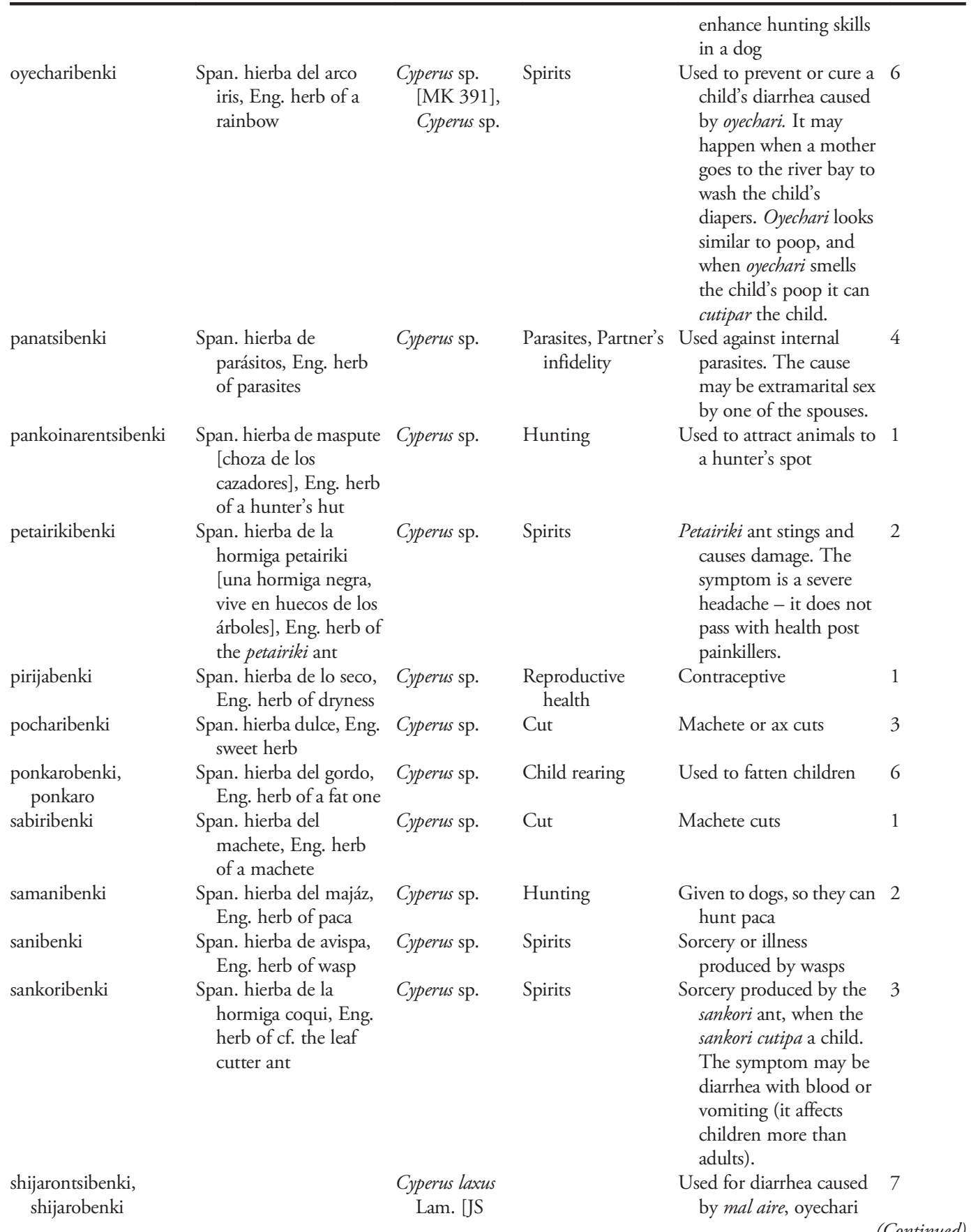


Table 1. (Continued).

\begin{tabular}{|c|c|c|c|c|c|}
\hline $\begin{array}{l}\text { Ashaninka } \\
\text { name/Ashaninka } \\
\text { folk species }\end{array}$ & $\begin{array}{l}\text { Spanish and English } \\
\text { translation of } \\
\text { Ashaninka name }\end{array}$ & $\begin{array}{l}\text { Botanical } \\
\quad \operatorname{taxon} / \text { no. } \\
\text { of } \\
\text { collection }\end{array}$ & "Category of Use & "Use & No. of \\
\hline & $\begin{array}{l}\text { Span. hierba de la } \\
\text { diarrea, Eng. herb of } \\
\text { diarrhea }\end{array}$ & $\begin{array}{l}\text { 193], } \\
\text { Cyperus } \\
\text { prolixus } \\
\text { Kunth [MK } \\
\text { 471], } \\
\text { Cyperus sp. } \\
\text { [MK 393], } \\
\text { Cyperus sp. }\end{array}$ & $\begin{array}{l}\text { Digestive } \\
\text { problems, } \\
\text { Spirits }\end{array}$ & $\begin{array}{l}\text { [rainbow], or due to } \\
\text { natural causes (eating } \\
\text { raw fish) }\end{array}$ & \\
\hline shimabenki & $\begin{array}{l}\text { Span. hierba del pescado } \\
\text { [boquichico], Eng. } \\
\text { herb of a fish } \\
\text { boquichico }\end{array}$ & Cyperus sp. & $\begin{array}{l}\text { Digestive } \\
\text { problems }\end{array}$ & $\begin{array}{l}\text { Diarrhea produced from } \\
\text { eating raw fish }\end{array}$ & 2 \\
\hline $\begin{array}{l}\text { shinkirerishi } \\
\text { (shiobana) }\end{array}$ & $\begin{array}{l}\text { Span. hoja del viento, } \\
\text { remolino, Eng. leaf of } \\
\text { the wind, swirl }\end{array}$ & Cyperus sp. & Spirits & $\begin{array}{l}\text { Children are especially } \\
\text { susceptible to strong } \\
\text { wind, which fills them } \\
\text { and produces } \\
\text { vomiting. }\end{array}$ & 1 \\
\hline shintoribenki & $\begin{array}{l}\text { Span. hierba del sajino, } \\
\text { Eng. herb of the } \\
\text { peccary }\end{array}$ & Cyperus sp. & Hunting & $\begin{array}{l}\text { Used for a dog, to make } \\
\text { him a good peccary } \\
\text { hunter }\end{array}$ & 1 \\
\hline shintsibenki & $\begin{array}{l}\text { Span. hierba de la } \\
\text { rapidez y fuerza, Eng. } \\
\text { herb of speed and } \\
\text { strength }\end{array}$ & Cyperus sp. & Child rearing & $\begin{array}{l}\text { Given to toddlers so they } \\
\text { walk fast and have } \\
\text { strength in their legs }\end{array}$ & 5 \\
\hline shiobana & $\begin{array}{l}\text { Span. hierba [generic } \\
\text { name for Cyperus } \\
\text { spp.], Eng. herb }\end{array}$ & $\begin{array}{l}\text { Cyperus cf. } \\
\text { odoratus L. } \\
\text { [MK 457], } \\
\text { Cyperus sp. }\end{array}$ & $\begin{array}{l}\text { Child rearing, } \\
\text { Digestive } \\
\text { problems, } \\
\text { Fractures, Hair, } \\
\text { Reproductive } \\
\text { health, Spirits }\end{array}$ & $\begin{array}{l}\text { Used in child rearing: fast } \\
\text { walking, fattening, } \\
\text { weaning, to protect the } \\
\text { child from mal aire; } \\
\text { against diarrhea; in } \\
\text { fracture healing; as } \\
\text { contraceptive; to } \\
\text { enhance hair growth; } \\
\text { healing from visions of } \\
\text { spirits and devil }\end{array}$ & 23 \\
\hline shiompatiribenki & $\begin{array}{l}\text { Span. hierba de las } \\
\text { vuletas, del remolino, } \\
\text { Eng. herb of swirls } \\
\text { and laps }\end{array}$ & $\begin{array}{l}\text { Cyperus cf. } \\
\text { odoratus [JS } \\
150], \\
\text { Cyperus sp. }\end{array}$ & Spirits & $\begin{array}{l}\text { Mal aire, a strong wind } \\
\text { that can capture the } \\
\text { spirit of a small child, } \\
\text { the symptoms may be } \\
\text { dizziness and vomiting }\end{array}$ & 2 \\
\hline $\begin{array}{l}\text { shipokantatsiribenki, } \\
\text { shipokantribenki, } \\
\text { shipokarontsibenki }\end{array}$ & $\begin{array}{l}\text { Span. hierba de } \\
\text { evaporación } \\
\text { sanadora, Eng. herb } \\
\text { of vopor healing }\end{array}$ & Cyperus sp. & Expert medicine & $\begin{array}{l}\text { Used in initiation for } \\
\text { those who heal by } \\
\text { using } \\
\text { mini-saunas/- } \\
\text { evaporation. It helps to } \\
\text { see the cause of an } \\
\text { illness }\end{array}$ & 4 \\
\hline shonkiribenki & $\begin{array}{l}\text { Span. hierba de una } \\
\text { clase de perdíz, Eng. } \\
\text { herb of a partridge }\end{array}$ & Cyperus sp. & Spirits & $\begin{array}{l}\text { When one follows a } \\
\text { sound from the forest, } \\
\text { when one has been }\end{array}$ & 1 \\
\hline
\end{tabular}


Table 1. (Continued).

\begin{tabular}{lccccc}
\hline \hline $\begin{array}{l}\text { Ashaninka } \\
\text { name/Ashaninka } \\
\text { folk species }\end{array}$ & $\begin{array}{c}\text { Spanish and English } \\
\text { translation of } \\
\text { Ashaninka name }\end{array}$ & $\begin{array}{c}\text { Botanical } \\
\text { taxon / no. } \\
\text { of } \\
\text { collection }\end{array}$ & Category of Use & Use & No. of \\
\hline
\end{tabular}

\begin{tabular}{|c|c|c|c|c|c|}
\hline & & & & $\begin{array}{l}\text { disturbed by an evil } \\
\text { spirit }\end{array}$ & \\
\hline soronkabenki & $\begin{array}{l}\text { Span. hierba de resbalar, } \\
\text { Eng. herb of slip off }\end{array}$ & Cyperus sp. & Childbirth & $\begin{array}{l}\text { Used during labor to ease } \\
\text { the pain and accelerate } \\
\text { the childbirth }\end{array}$ & 1 \\
\hline taemperibenki & $\begin{array}{l}\text { Span. hierba de la } \\
\text { hormiga taemperi } \\
\text { [familia de coqui], } \\
\text { Eng. herb of the } \\
\text { taemperi ant }\end{array}$ & Cyperus sp. & Spirits & $\begin{array}{l}\text { Used when the taemperi } \\
\text { ant produces sorcery, } \\
\text { the symptoms may be } \\
\text { little grains and } \\
\text { pimples on the skin. } \\
\text { The healing action } \\
\text { includes the burning of } \\
\text { the ant nest }\end{array}$ & 3 \\
\hline tampiabenki & $\begin{array}{l}\text { Span. hierba del viento, } \\
\text { Eng. herb of the wind }\end{array}$ & Cyperus sp. & Spirits & $\begin{array}{l}\text { Mal viento [bad wind], } \\
\text { mal aire }\end{array}$ & 1 \\
\hline tarontsibenki & $\begin{array}{l}\text { Span. hierba de la } \\
\text { quemdura, Eng. herb } \\
\text { of burn }\end{array}$ & Cyperus sp. & Horticulture & $\begin{array}{l}\text { The rhizome is blown } \\
\text { over the garden, before } \\
\text { the weeds are burnt - it } \\
\text { helps to control the } \\
\text { fire. }\end{array}$ & 1 \\
\hline tiatsibenki & $\begin{array}{l}\text { Span. hierba del } \\
\text { excremento-- } \\
\text { defecación, Eng. herb } \\
\text { of stool-defecation }\end{array}$ & Cyperus sp. & Child rearing & $\begin{array}{l}\text { Given to babies so they } \\
\text { don't poo very often }\end{array}$ & 3 \\
\hline $\begin{array}{l}\text { timakorentsibenki, } \\
\text { timakoribenki }\end{array}$ & $\begin{array}{l}\text { Span. hierba para nacer, } \\
\text { Eng. herb of being } \\
\text { born }\end{array}$ & Cyperus sp. & Childbirth & $\begin{array}{l}\text { Used to ease pain and } \\
\text { accelerate labor. It may } \\
\text { be also used by an } \\
\text { accompanying } \\
\text { husband. }\end{array}$ & 4 \\
\hline tsanentsibenki & & Cyperus sp. & Partner's infidelity & $\begin{array}{l}\text { When one of the spouses } \\
\text { has extramarital sex, } \\
\text { the child may have a } \\
\text { chest hoarseness. It is } \\
\text { the unfaithful partner } \\
\text { who must cure the } \\
\text { child. }\end{array}$ & 1 \\
\hline tsimenkitobenki & $\begin{array}{l}\text { Span. hierba del carbón, } \\
\text { Eng. herb of charcoal }\end{array}$ & Cyperus sp. & Expert medicine & $\begin{array}{l}\text { Used by experts in } \\
\text { mini-sauna /vapors. It } \\
\text { help them to diagnose } \\
\text { the cause of an illness. } \\
\text { Charcoal found in } \\
\text { evaporation is under- } \\
\text { stood as a sign of a } \\
\text { sorcery. }\end{array}$ & 1 \\
\hline tsimeribenki & $\begin{array}{l}\text { Span. hierba del pajarito } \\
\text { tsimeri, Eng. herb of } \\
\text { the tsimeri bird }\end{array}$ & Cyperus sp. & Food proscription & $\begin{array}{l}\text { When parents eat birds, it } \\
\text { may affect their baby. } \\
\text { The bird may cutipar } \\
\text { the baby and s/he }\end{array}$ & 1 \\
\hline
\end{tabular}


Table 1. (Continued).

\begin{tabular}{|c|c|c|c|c|c|}
\hline $\begin{array}{l}\text { Ashaninka } \\
\text { name/Ashaninka } \\
\text { folk species }\end{array}$ & $\begin{array}{l}\text { Spanish and English } \\
\text { translation of } \\
\text { Ashaninka name }\end{array}$ & $\begin{array}{l}\text { Botanical } \\
\text { taxon / no. } \\
\text { of } \\
\text { collection }\end{array}$ & Category of Use & Use & No. of \\
\hline
\end{tabular}

\begin{tabular}{|c|c|c|c|c|}
\hline & & & & $\begin{array}{l}\text { follows its sound at } \\
\text { night, does not sleep } \\
\text { well. }\end{array}$ \\
\hline $\begin{array}{l}\text { tsomirontobenki, } \\
\text { tsomirotsibenki }\end{array}$ & $\begin{array}{l}\text { Span. hierba de la teta, } \\
\text { pezón [tsomitsi], } \\
\text { desmamar } \\
\text { [tsomirontsi], Eng. } \\
\text { herb of breast, nipple, } \\
\text { weaning }\end{array}$ & Cyperus sp. & Child rearing & Used for child weaning \\
\hline tsomontebenki & $\begin{array}{l}\text { Span. hierba del } \\
\text { embarazo, gestación, } \\
\text { Eng. herb of } \\
\text { gestation }\end{array}$ & Cyperus sp. & $\begin{array}{l}\text { Childbirth, Food } \\
\text { proscriptions, } \\
\text { Reproductive } \\
\text { health }\end{array}$ & $\begin{array}{l}\text { Used to ease pain and } \\
\text { accelerate labor. It may } \\
\text { be also used by the } \\
\text { accompanying } \\
\text { husband; also used } \\
\text { when a woman wants } \\
\text { to get pregnant; when a } \\
\text { parturient woman eats } \\
\text { the game meat of her }\end{array}$ \\
\hline
\end{tabular}

(Continued)

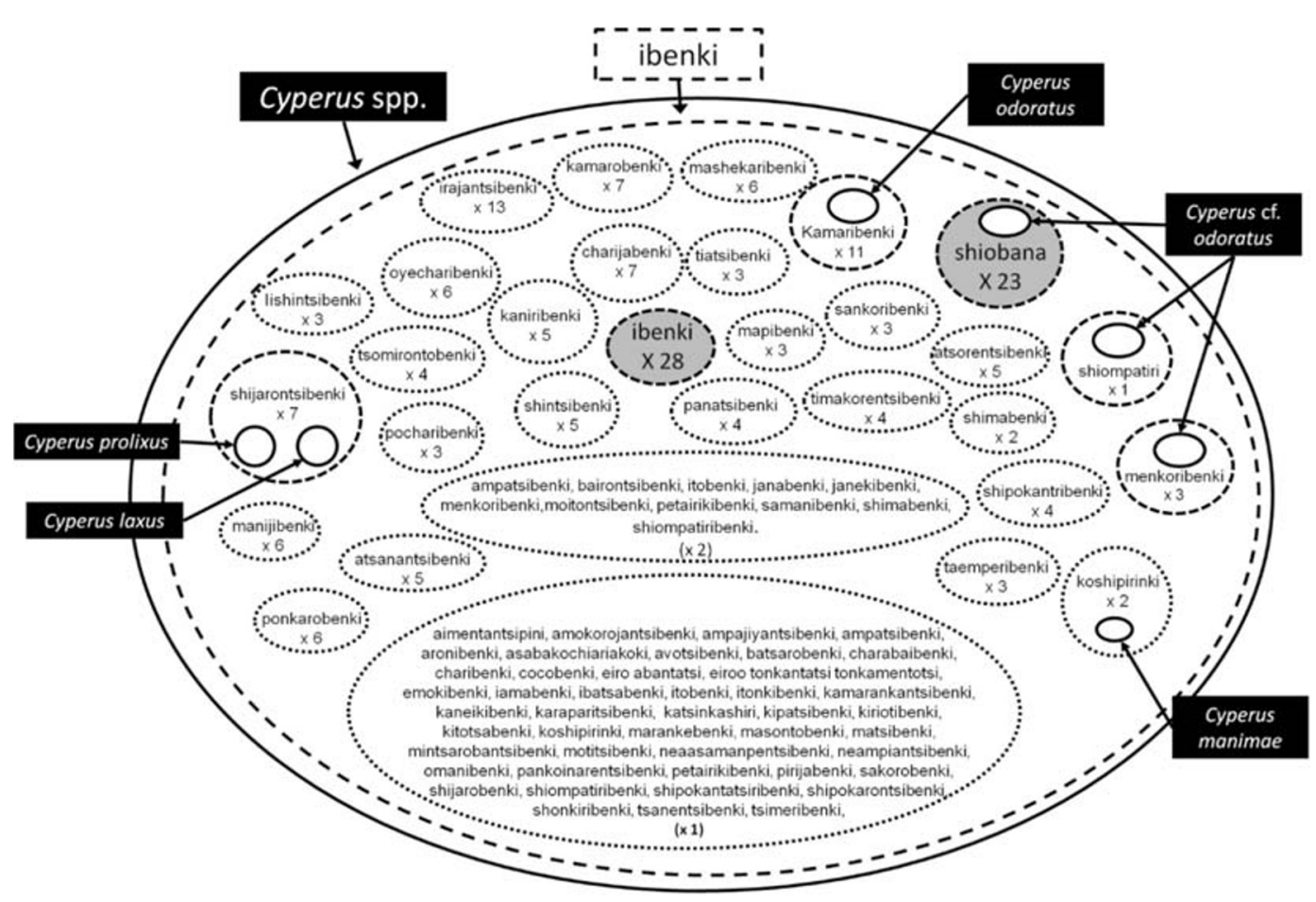

Fig. 3. Venn diagrams presenting a scheme of the Ashaninka groupings of the domesticated Cyperus spp. Legend: The numbers below ibenkis names stay for a number of mentions (number of exemplars) for each folk species 
shape of the plant, but the use-food proscriptions, in this case. Other names evoke non-humans such as animals, including insects and fish, spirits and spirits of dead people, natural phenomena, and minerals. Another group of semantic constituents are health problems and symptoms: cuts, wounds, diarrhea, vomits, being in pain (Ash. katsi), and others. Occasionally, secondary lexemes refer to actions, such as hunting, fishing and witchcraft (all Ashaninka names translated to Spanish and English are found in the Table 1). The meaning of names strongly corresponds to Ashaninka cosmology and ontological categories, and reveal many levels of connectivity between the Ashaninka and nonhumans.

The names of folk species contain mnemonic cues to differentiate otherwise morphologically similar plants. The mnemonic cues are loaded with meaning, and apart from the generic suffix-iben "an herb" - they have no reference to morphology. This does not mean that our findings automatically support the utilitarian flank in the ethnoclassification debate (Nazarea 1999; Randall and Hunn 1984), one which highlights the utilitarian ends of the biological ethnoclassification. We instead agree with Balée (1994) and Ihde and Malafouris (2018) that there exists a strong relationship between cognition and the material world, i.e., the cognitive aspects of ibenki-their naming and grouping-are embedded in Ashaninka practices and experiences of domesticating, tending, using, and exchanging these plants. On the other hand, we worked with highly culturally-important plants in an entirely anthropogenic habitat, where the connection between classification, cultural categories, and ontology are strong (Ellen 1993).

Tournon (1991) asks questions about the Shipibo-Conibo names of specific huaste (Cyperus). Namely, whether these are true names or mere descriptions or maybe these names are an improvisation in front of the ethnographer? According to this author, the true name is the one that belongs to the shared culture, and whose reproduction relies on transmission from one interlocutor to another. Tournon's point is that some of the descriptive names cannot be mere improvisations by the interlocutor, as they contain information that is valid to the local culture.

We asked a similar question to Tournon's: what potential have names of specific ibenki for reproduction in the cultural sphere through transmission? By using consensus analysis (Trotter and Logan 1986), we established that the mean score for consensus among all folk species was relatively high (0.85), showing that the names have real communicative value and people share understanding of uses behind the names (Fig. 4). This is also supported by the fact that active constituents of secondary lexemes are loaded with meanings that are generally comprehended and shared by the Ashaninka. An example may be here manijibenki, "herb of bullet ant" [isula in local Amazonian Spanish], which is a stinging ant (cf. Paraponera or Dinoponera). Most of Ashaninka people have seen the maniji, some have been stung by the ant and suffered from the strong pain it produced. The cultivated manijibenki is not applied on a swollen part of the body or to soothe the pain. Ashaninka say that maniji captures the spirit of an adult or a child: "vamos a la chacra, trabajamos, allí está el panal de la isula, ella ya nos miró, ya nos brujeó" ("we go to the garden, we work, there is an isula nest, she has already watched us, she has bewitched us already"). In ontological relations, maniji, similarly to other ants, is considered a matsi "a sorcerer." The sorcerers harm others by manipulating food remains or some corporeal remains of the people they wish to harm. The Ashaninka see an analogy between ants and sorcerers - ants take food remains left by people (Rojas 2003). From the Ashaninka perspective, the maniji bewitches people, producing general body pain or pain in a particular part of the body. Manijibenki is used by the Ashaninka against the sorcery ascribed to the bullet ants. The symptoms are general body pain or pains in certain parts of the body (but which are not effects of the ants stinging). Therefore, we agree with Tournon (1991) in that the descriptive names (secondary lexemes) cannot be the improvisations of interlocutors in front of the researcher, in our case. There is a consistency between the information they are loaded with and the shared interpretation of this information.

However, the modified consensus index shows that the overall community consensus on use decreases (from mean 0.85 to mean 0.28 ) when the spatial correction factor is introduced in the formula, which would support the idea that specific ibenki and their names circulate on a small scale, probably among closely related people. This is supported by the notion of the ownership of domesticated sedges: on several occasions we were told that a certain ibenki "does not belong to me" or "is of my husband." The names are not revealed easily to nonrelated people. As some interlocutors stressed, it might undermine the power and action of ibenki. 


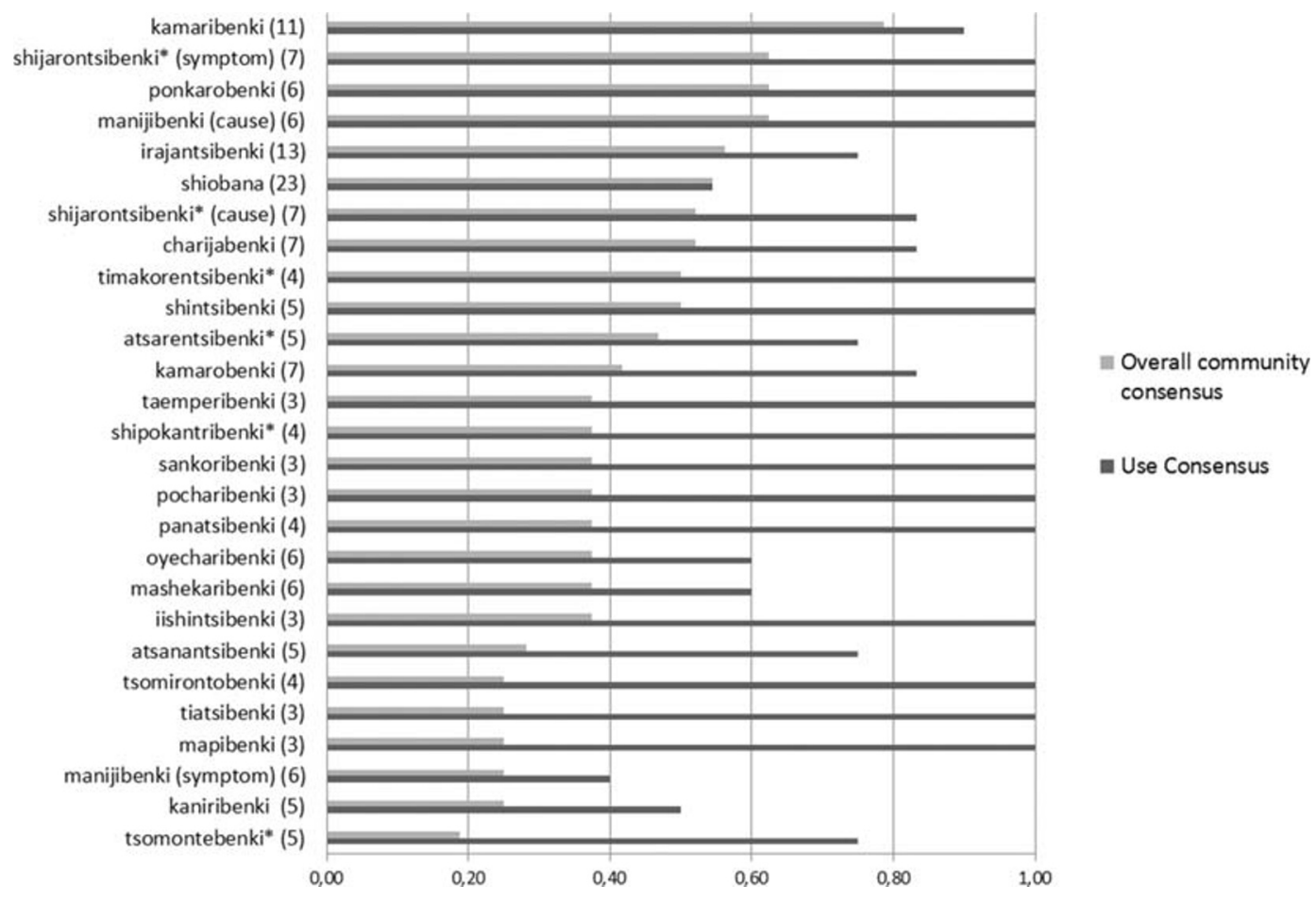

Fig. 4. Consensus on use and overall community consensus on the use (i.e., folk species distribution across the communities) of ibenki folk species (mentioned at least three times within 12 Ashaninka communities along the Tambo River, Peru). Legend: The number of mentions is shown in brackets (). $\rightarrow$ indicates that synonyms for these folk species were found (see Table 1)

It is likely that as in the myth of origin of the ibenki, the Ashaninka receive, and then share the ibenki with their names in a similar way to that which the sankori ant did, i.e., as a secret that is passed between kin or a household group.

Folk species with the highest overall community consensus were kamaribenki (0.53) ("herb of the devil"), followed by manijibenki (cause), ponkarobenki ("herb of a fat one"), and shijarontsibenkil shijarobenki (symptom) ("herb of diarrhea"), all with a 0.42 consensus score. Shijarontsibenki has a great consensus on use (1) but was only cited in five of the 12 communities studied, so when incorporating the spatial correction factor, the overall community consensus drops markedly below 0.5 (Fig. 4).

There is a relationship between a single plant name and a single plant use; in other words, folk species of ibenki very rarely have more than one use/ application reported by a given person (which is also expressed in a similar overall number of exemplars, mentions, and use reports). Despite the low individual versatility, the versatility of the whole set of domesticated sedges is very large, which accounts for its resilience. This phenomenon of low individual versatility seems to corroborate the idea that ibenki are plant-persons.

\section{IBENKI-ANTIDOTES, AlLIES AND AgENTS OF TRANSFORMATION}

Everyday Ashaninka dwelling in the world is intimately related to the knowledge and use of plants, which rests on a shared ontological basis. There are some regularities and continuities observed in the use of Cyperus. We arranged the whole array of recorded uses into three overarching categories, based on causes (of illness, social disruption), actions (medicinal and beyond), and symptoms. There are misfortunes and illnesses for which the Ashaninka clearly identify their cause, or even describe a given condition through the etiological lenses. These cause-driven health conditions treated with the help of ibenki are mentioned with the 
highest frequency. The main causes are: partners' infidelity, inadequate behavior of parents of a small child, breaking taboos, and intentional actions of other humans and non-humans, including spirits and animals. Out of 258 total use reports, 123 UR (48\%) directly report causes within the abovementioned categories. The focus on illness origin in dealing with the healing process, or understanding the cause as a prerequisite in recovering from an illness, has also been described in different Amazonian groups (see inter alia: Belaunde 2001; Heckler 2007; McCallum 1996).

Another overarching category in which ibenki are used is what we call "actions." In the Ashaninka scenario, ibenki are involved in actions related to childbirth (to accelerate labor, to ease pain, to counteract hemorrhaging, to remove the placenta); child rearing; fishing, hunting, and agriculture activities; actions taken in case of bites, cuts and fractures; as well as in case of violence. These types of uses account for 78 UR ( $30 \%$ of all UR). In some cases actions should be understood as hyperbole — a part that stands for the whole. For example, one interlocutor mentioned that he had kamarobenki (herb of a she-devil), which he used to heal his shotgun when he didn't have luck in hunting. According to Ashaninka etiologies, bad luck in fishing or hunting is usually attributed to food proscriptions, namely transgressing food prohibitions by his menstruating daughter or wife. Did our interlocutors prefer to mention just an action or even a symptom without revealing a "real" cause? Therefore, this category is a compromise between our potential oversights in asking specific questions and/ or the interlocutors' omissions. However, the question here may be whether these omissions in revealing the causes do not indicate an on-going process of loosening relationships between cause and cure among the Ashaninka. This would indicate a slow process of expanding symptom-specific treatment to the detriment of cause-centered healing (see Heckler 2007). This would also mean that ibenki may lose their positions as plant-persons, kin, and allies to the Ashaninka, and be reduced to "antidotes" at best or just "useful resources" to counteract an illness, symptom, or a misfortune. Our findings show, however, that ibenki are rarely used to counteract mere symptoms ( 31 UR out of $258 ; 12 \%$ ), such as digestive problems, intestinal parasites, respiratory, skin, fever, and different kinds of pain, which are not directly related to culturally defined etiologies. In one community, we met a man whose wife was diagnosed with diabetes and he was in search of a "good" medicine for her. He told us that someone had told him about ibenki for diabetes, and he was determined to find it. This case suggests that ibenki are suitable to change and adaptation to new cultural and health circumstances. When the Ashaninka experienced the social unrest and horror of Sendero Luminoso's (Shining Path) activity in their territory in the 1980 s and early 1990 s (Varese 2006), Ashaninka men cultivated Eiro otonkantatsi tonkamentotsi ("I am responding with a shotgun"), a special ibenki to intimidate their enemies. Overall, ibenki, culturally important and distinguished plants, are allies in maintaining specific Ashaninka (or indigenous Amazonian) relations between humans and animals and in counteracting prohibitions. This is the core function of ibenki, on the periphery; however, as a response to current circumstances, new functions of these powerful plants emerge and a new agency is ascribed to them.

Following the approach of Plowman et al. (1990) and Lewis and Elvin-Lewis (1990), and taking into consideration those ailments that correspond to Western biomedical categories, our findings are in line with these authors' conclusions. Ibenki are used extensively to counteract bleeding (ergot alkaloids cause vasoconstriction) and to reduce pain during the childbirth (inducing uterine contractions). Most probably, due to the latter property of ergot alkaloids, different ibenki contribute to diverse fertilityrelated uses, expressed in ibenki's name and ascribed properties: atsorentsibenki ("dilator herb"), bairontsibenki ("herb of the name" - to help women get pregnant), eiro abantatsi ("I don't have a child"), motitsibenki ("herb of being pregnant"), etc. The treatment based on symptoms and some "actions," where reducing pain and counteracting bleeding is at stake, may be sustained by the pharmacological properties of Cyperus spp. and the associated fungus. In other words, many of the Ashaninka uses of Cyperus appear coherent with physiological properties of ergot alkaloids. The use of some specific ibenki to counteract diarrhea may be attributed to tannins and saponins present is some Cyperus species, but more study is needed in this respect. Chemosensory experience (sensu Daly and Shepard 2019) possibly may have influenced the Ashaninka understanding of etiology and efficacy, although expressed in their own cosmological terms. However, the general over-differentiation of Cyperus spp. with just one case of under-differentiation together with the broad range of uses show that phytochemical factors of the genus Cyperus are not 
sufficient to explain the attribution of uses by the Ashaninka. Therefore, we need to turn somewhere else to better understand the agency of the ibenki.

A plethora of Amazonian ethnographic literature concentrates on the body, cultural fabrication, and natural instability of the body (reviewed by Vilaça 2005). Amazonian ethnographies have shown that the body "is made by others in a constant flow involving nutrition, abstention, and application of medicines" (McCallum 1996: 352). In other words, the body is not constructed individually, and its growth is not a natural fact, but requires a collective to be made (Seeger et al. 1979; Tola 2005). This collective usually involves parents and kin, the household group, or the local group but also nonhumans, such as spirits (Tola 2012). Few ethnographies/studies include plants as agents participating in body making or transformation (Barúa 2007 after Tola 2012; Santos-Granero 2012; Shepard 1998). Our study shows that plants, ibenki in this case, participate actively in fabricating the bodies and in their transformation. Specific ibenki used in child rearing may serve as one such example, to enhance some desired qualities in children: to walk fast (shintsibenki "herb of speed and strength"): trabajamos, vamos a la chacra, que el niño ande rápido, que no quede sentado ("we work, we go to the garden, we need the child to walk fast, not to be seated"), to be nicely fat (ponkarobenki "herb of a fat one"), to have appetite (mashekaribenki "herb of lack of appetite"), to be weaned (tsomirontsibenki "herb of weaning"), to reduce defecation (tiatsibenki "herb of stool-defecation"), or not to eat the soil (kipatsibenki "herb of soil"). Some authors remark on the fact that in child rearing the use of particular plants may be connected to the transfer of morphologically visible plant qualities to children (SantosGranero 2012). Since all ibenki are morphologically similar, this is not a visible quality that is transferred but a notion of inherent interior qualities. According to the local cosmologies, eating others can produce kin-ibenki are not eaten in a food context, but the juice of the rhizome is ingested.

Ibenki also participate in maintaining the bodies (persons) connected. The important feature of the Ashaninka body construction and transformation is that the action of one person has strong implications for his/her family and non-humans too-here it makes sense to refer to the theory of connected bodies (Tola 2005, 2012), whereby "if the whole body contains elements that make it dependent on others (...) and that accounts for the mutual dependencies that are woven with other human beings, with non-humans and with the cosmic order in general, it usually happens that when men and women do not respect certain taboos, the balance in the universe and in social life is altered" (our translation, Tola 2012: 309). Instances of partner's infidelity provide a good ethnographic example for such a theory. When spousal infidelity has consequences for the child's health, leading to a chesty hoarseness and cough that is distinct to bronchitis, and referred to as ronquera. In such cases, atsanantsibenki ("herb of egoism") or atsanabenki ("herb of cheating") may be given to the child by the parent who has cheated. In this case, e.g., atsanantsibenki ("herb of egoism") or atsanabenki ("herb of cheating") is given to the child (it should be the parent who has cheated, who gives the medicine- a rhizome to the child).

Another example requires an understanding of the Spanish term cutipar, which means to copy, gain, or assimilate the characteristic of the other, as it was explained to us by the Ashaninka collaborators. In most cases these are animals and plants which can cutipar, i.e., a person gains the characteristic of a given species of animals or plants. Unborn children and infants are especially vulnerable to being cutipado (passive form of the verb cutipar) by animals and plants. The general idea is that a child will take the characteristic of a fruit or an animal which his/her mother ate while being pregnant. Therefore, pregnant women are careful with what they eat. But some gestating women are tempted by game meat, or by other prohibited kinds of fish or fruits. One of the principal causes for which medicinal plants are taken is the lack of maintaining a proper diet by gestating women. A typical symptom is pain during labor. For these occasions they cultivate ibenki which act as an antidote, and take them to counteract the effects of the proscribed food. Some of plants are taken during pregnancy starting from the fifth or seventh month (e.g., itonkibenki "herb of a bone"), and others when labor starts, to ease the pain. Sometimes women know precisely what animal or plant had them cutipado. Hence, they take cocobenki "herb of coco" or charijabenki "herb of a fishing net" before childbirth. When a child is born, both of the parents are subjected to a restricted diet, especially avoiding some kinds of game meat. Even the simple act of them walking in the forest may affect the infant. This is explained by the fact that the fragile spirit of a child always accompanies the parents. In the Ashaninka scenario, the healthy growth of a fetus and later a child depends on the parents' behavior, 
including food abstention and displacement in different habitats-especially in the forest, where the chance to encounter potentially malevolent spirits is higher than in the community.

Children in Amazonian cultures are kin with bodies and personalities in formation (Descola 2012; Fortis 2010; Medrano 2013; Tola 2012), therefore they are more likely to be cutipado. The children's body and personality are transformed into kin-allied bodies through the endowment of various properties, among which are those that the specific ibenki of each family are equipped with. The construction of bodies-relatives-allies, the transfer of some desired qualities to children, as counteracting unwanted properties of being cutipado inscribes in an anthropological concept of "contagion,", and what Descola calls "the traffic of souls" (based on the schema of generalized predation around tsantsa ritual) (Descola 2012). In this sense the ibenki are corps-relatives-allies with multiple agencies in a similar way to those handled by a sorcerer or shaman, capable of capturing or containing properties that are desired to counter others. In the examples described in this section, we observe contagions from animals and plants (desired or unwanted) to people and among people, such as that of the unfaithful spouse to the child, in a similar way to that observed among the Q'om of the Argentine Chaco (Medrano 2013). These contagions occur at different intensities throughout the life cycle of people (i.e., cycle of transformations).

\section{Exchange of Plant Material}

We recorded 86 different folk species (specific ibenki), which correspond to 255 exemplars in 58 Ashaninka home gardens, belonging to 64 persons. Women $(N=53)$ reported between 1 and 11 (mean 4.4) and men $(N=11)$ reported between 1 and 6 (mean 2) ibenki in their home gardens. Women usually cultivate ibenki for a wide array of uses for themselves, their children, household protection, etc., while men tend to have specified ibenki for a limited number of uses, for example ensuring good hunting and hunting skills, and against bites and cuts.

The names and uses of ibenki mostly circulate on a small scale and their circulation decreases when the spatial factor (number of communities) is taken into account. Propagules of ibenki are more often obtained within the same community (39\%) than from a different community (32\%), and we do not have data on 73 exemplars (29\%). The owners of these exemplars did not want to reveal or could not remember where they had obtained their ibenki.

Our data suggests that plants are primarily exchanged and obtained along kinship lines (127 out of $255-50 \%$ ), from affined, such as parents-in-law or brothers-in-law (29 exemplars); non-related people (24); purchased (3). But we do not have data on 72 exemplars (28\%) in this respect (Fig. 5).

In most cases, these are adult children who inherit ibenki from their parents across gender lines ( $\mathrm{F}$ to $\mathrm{F}$, $\mathrm{M}$ to $\mathrm{M}$ ), but not always. Due to the displacement of many Ashaninka people during the abovementioned Shining Path guerrilla-like activity in the Ashaninka territory, many Ashaninka people fled to the forest, taking only the most essential belongings with them, often leaving their ibenki behind. We met a few elderly women who managed to obtain and plant some ibenki from their granddaughters and nieces.

Similar to other domesticated plants, such as staples cassava and bananas, or coca and tobacco, ibenki have a privileged position in Ashaninka society and grow in almost every garden. Wild growing Cyperus spp. are disregarded, and not included in the entangled relationships. We collected a wild growing Cyperus luzulae (L.) Retz. [v.s. MK 360] (with well-developed inflorescences), but when we asked our interlocutors about its use, they stated that "esto no sirve" (it does not work). This high position of domesticated Cyperus does not stem from the fact that these plants need active tending and management. It is the ibenki personhood, their entitled position as kin to the Ashaninka and their incorporation in ontological relations that make them so important and resilient. This complex, multilayered relationship must have been created in the past, which is beyond Amazonian chronicles, ethnographies, and life memories, and have persisted until now.

\section{Conclusions}

The understanding of plant-people relations is certainly informed by one's own theoretical inclinations. We engage with the growing field of the more-than-human framework in the humanities (e.g., Guzmán-Gallegos 2019), which attempts to dethrone humans from their privileged position and put them in "rhizomatic-like" inter-species relations. We also propose calling our method of analysis the more-than-utility approach to ethnobotany. By proposing the more-than-utility approach, we 

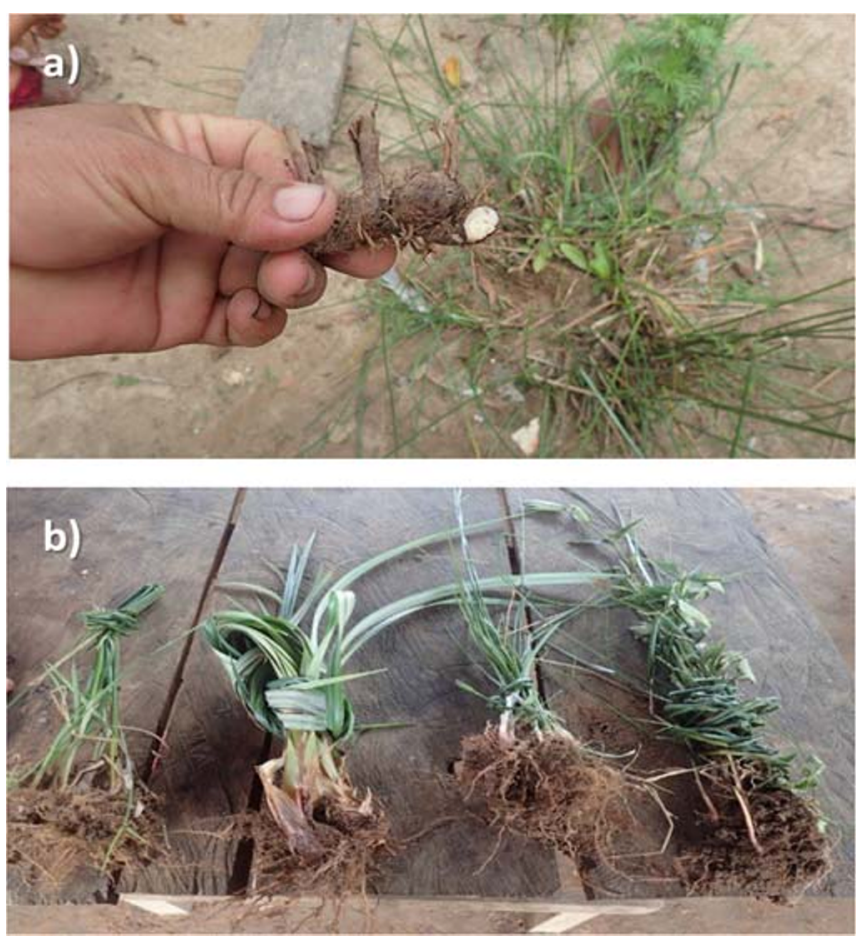

Fig. 5. Different ibenki exchanged by related women. a) The rhizome is crucial—many times, when someone shows their ibenki they dig out a piece of rhizome to show; b) ibenki prepared by an owner of the garden for her aunt to take home (on the table from the left: three different kinds of ibenki, extreme right one ibinishi-Justicia sp.)

do not wish to engage in the ongoing debate between universal / intellectual versus utilitarian flanks in ethnobiological classification, as we understand our approach in a wider sense, one that is not limited to recording and analyzing uses that local communities ascribe to plants. Most definitions of ethnobotany highlight uses as a scope of ethnobotanical interest. We think that in some cases, like ours, taking into account ontological categories, nomenclature, and exchange of plants, together with uses, enables us to understand deep and longlasting plant-people relationships. The balance of commitment between these elements (oral history [myths], folk classification, uses and etiologies, and plant circulation) highlights certain nodes in an approximation, used in this study, when forming a network of meanings. Nevertheless, the proposed analytical sequences in this study are not considered as a context-free operational model or method.

The paper leaves a clear vision of the importance of a certain plant group, of which the Flora of Peru registered 30 Cyperus species in Peruvian Amazonia. Certainly more botanical taxonomic study is needed in this respect. At the same time Ashaninka indigenous people from Peruvian Amazonia have solved the taxonomic problem for themselves by endowing several domesticated species of Cyperus (we counted 4) with 86 different names, and corresponding uses, treating them as discrete (folk) species. The prepared diagrams (Fig. 3) place two systems of classification (two epistemological approaches) in dialog and highlight the magnitude of this phenomenon. A possible shortcoming of this paper is the insufficient number of voucher specimens and precise botanical identification of a larger number of Cyperus spp., in order to attempt to correlate them with ibenki. The identification of the ibenki and their close relationship with the Ashaninka people has been confirmed by the rigorous analysis in this study. However, the botanical species and folk-species relationship has yet to be elucidated, assuming that in this process the Ashaninka have quite possibly contributed to the domestication of these important, from a biodiversity perspective, resources. 


\section{Acknowledgments}

We are grateful to the study participants and the CART authorities of the Tambo River region. This project was funded by the Polish National Science Centre, grant no. 2015/19/D/HS3/00632. The authors are extremely grateful to Miguel Alexiades who agreed to read several versions of this manuscript and gave insightful comments and critiques which have contributed to the gradual improvement of the manuscript. Monika Kujawska is grateful to the Polish National Agency for Academic Exchange. During her fellowship at the University of Kent (PPN/BEK/2018/1/00198/U/00001), she could discuss used methods of analysis with Prof. Roy Ellen and Dr. Rajindra Puri.

Open Access This article is licensed under a Creative Commons Attribution 4.0 International License, which permits use, sharing, adaptation, distribution and reproduction in any medium or format, as long as you give appropriate credit to the original author(s) and the source, provide a link to the Creative Commons licence, and indicate if changes were made. The images or other third party material in this article are included in the article's Creative Commons licence, unless indicated otherwise in a credit line to the material. If material is not included in the article's Creative Commons licence and your intended use is not permitted by statutory regulation or exceeds the permitted use, you will need to obtain permission directly from the copyright holder. To view a copy of this licence, visit http://creativecommons.org/licenses/by/4.0/.

\section{Further Reading}

Almeida, S. S. de. 2010. As pripriocas: Seus aromas e suas estruturas. Boletim Do Museu Paraense Emilio Goeldi. Ciencias Humanas 5: 195-196.

Ayala Flores, F. 2003. Taxonomía vegetal: Gymnospermae y Angiospermae de la Amazonía Peruana. Iquitos.

Babu, R. H. and N. Savithramma. 2014. Screening of secondary metabolites of underutilized species of Cyperaceae. International Journal of Pharmaceutical Sciences Review and Research 24(2): 182-187.

Balée, W. 1994. Footprints of the forest: Ka'apor ethnobotany-The historical ecology of plant utilization by an Amazonian people. New York: Columbia University Press.
Barúa, G. 2007. Un arte delicado. Relaciones entre el parentesco, el conflicto y el acontecimiento entre los wichi del chaco central. Buenos Aires: Dunken.

BDPI. 2020. Base de Datos Oficial de Pueblos Indígenas u Orginarios, Ministerio de Cultura, Peru. https://bdpi.cultura.gob.pe/pueblos/ ashaninka.

Belaunde, L. E. 2001. Viviendo bien. Género y fertilidad entre los airo-pa de la Amazonía peruana. Lima: Centro Amazónico de Antropología y Aplicación Práctica.

Bennett, B. C. 1992. Hallucinogenic plants of the Shuar and related indigenous groups in Amazonian Ecuador and Peru. Brittonia 44(4): 483-493.

Berlin, B. 1992. Ethnobiological classification: Principles of categorization of plants and animals in traditional societies. Princeton: Princeton University Press.

Berlin, B., D. E. Breedlove, and P. H. Raven. 1974. Principles of Tzeltal plant classification. An introduction to the botanical ethnography of a Mayan-speaking peoples of highland Chiapas. New York and London: Academic Press.

Boster, J. S. 1986. Exchange of varieties and information between Aguaruna manioc cultivators. American Anthropologist 88(2): 428-436.

Caballero-Serrano, V., B. McLaren, J. C. Carrasco, J. G. Alday, L. Fiallos, J. Amigo, and M. Onaindia. 2019. Traditional ecological knowledge and medicinal plant diversity in Ecuadorian Amazon home gardens. Global Ecology and Conservation 17: e00524.

Cipolletti, M. S. 1988. El piri-piri y su significado en el shamanismo secoya. Amazonía Peruana 15: 83-97.

Daly, L. 2015. What kind of people are plants? The challenges of researching human-plant relations in Amazonian Guyana. Engagement, Blog of the Anthropology and Environment Society, AAA.

Daly, L. and G. Shepard. 2019. Magic darts and messenger molecules: Toward a phytoethnography of indigenous Amazonia. Anthropology Today 35(2): 13-17.

Descola, P. 1996. La selva culta. Simbolismo y praxis en la ecología de los achuar. Quito: Ediciones ABYA-YALA.

- 2012. Beyond nature and culture: The traffic of souls. HAU: Journal of Ethnographic Theory 2(1): 473-500.

Desmarchelier, C., E. Mongelli, J. Coussio, and G. Ciccia. 1996. Studies on the cytotoxicity, antimicrobial and DNA-binding activities of plants 
used by the Ese'ejas. Journal of Ethnopharmacology 50(2): 91-96.

Dhillon, R. S., S. Singh, S. Kundra, and A. S. Basra. 1993. Studies on the chemical composition and biological activity of essential oil from Cyperus rotundus Linn. Plant Growth Regulation 13(1): 89-93.

Díaz-Reviriego, I., L. González-Segura, A. Fernández-Llamazares, P. L. Howard, J. L. Molina, and V. Reyes-García. 2016. Social organization influences the exchange and species richness of medicinal plants in Amazonian homegardens. Ecology and Society 21(1): 1.

Ellen, R. F. 1993. The cultural relations of classification: An analysis of Nuaulu animal categories from Central Seram. Cambridge: Cambridge University Press.

Ferrero, A. O. P. 1966. Los Machiguengas. Tribu selvática del sur-oriente peruano. Puerto Maldonado: Instituto de Estudios Tropicales "Pio Aza".

Fortis, P. 2010. The birth of design: A Kuna theory of body and personhood. Journal of the Royal Anthropological Institute 16(3): 480-495.

Giovannini, P. 2015. Medicinal plants of the Achuar (Jivaro) of Amazonian Ecuador: Ethnobotanical survey and comparison with other Amazonian pharmacopoeias. Journal of Ethnopharmacology 164: 78-88.

Guzmán-Gallegos, M. A. 2019. Philippe Descola: Thinking with the Achuar and the Runa in Amazonia. Ethnos, 1-18. https://doi.org/10. 1080/00141844.2019.1580759.

Heckenberger, M. 2005. The ecology of power: Culture, place, and personhood in the southern Amazon, AD 1000-2000. New York: Routledge.

Heckler, S. L. 2007. Herbalism, home gardens and hybridization. Wôthïhã medicine and cultural change. Medical Anthropology Quarterly 21: 41-63.

Hill, J. D. and F. Santos-Granero, eds. 2002. Comparative Arawakan histories: Rethinking language group and culture area in Amazonia. Urbana: University of Illinois Press.

Ihde, D. and L. Malafouris. 2018. Homo faber revisited: Postphenomenology and material engagement theory. Philosophy and Technology 32: 195-214.

Kilani, S., M. B. Sghaier, I. Limem, I. Bouhlel, J. Boubaker, W. Bhouri, I. Skandrani, A. Neffatti, R. B. Ammar, M. G. Dijoux-Franca, K. Ghedira, and L. Chekir-Ghedira. 2008. In vitro evaluation of antibacterial, antioxidant, cytotoxic and apoptotic activities of the tubers infusion and extracts of Cyperus rotundus. Bioresource Technology 99(18): 9004-9008.

Lewis, W. H. and M. Elvin-Lewis. 1990. Obstetrical use of the parasitic fungus Balansia cyperi by Amazonian Jivaro women. Economic Botany 44(4): 131-133.

Lewis, W. H., M. Elvin-Lewis, and M. C. Gnerre. 1987. Introduction to the ethnobotanical pharmacopeia of the Amazonian Jivaro of Peru. In: Medicinal and poisonous plants of the tropics. Proceedings of Symposium 5-35 of the 14th International Botanical Congress, Berlin, ed. A. J. M. Leeuwenberg, 96-103. Wageningen: Centre for Agricultural Publishing and Documentation.

Luziatelli, G., M. Sørensen, I. Theilade, and P. Mølgard. 2010. Asháninka medicinal plants: A case study from the native community of Bajo Quimiriki, Junín, Peru. Journal of Ethnobiology and Ethnomedicine 6: 21. https://doi.org/10. 1186/1746-4269-6-21.

McCallum, C. 1996. The body that knows: From Cashinahua epistemology to a medical anthropology of lowland South America. Medical Anthropology Quarterly 10(3): 347-372.

Medrano, C. 2013. Devenir-en-transformación. Debates etnozoologicos en torno a la metamorfosisi animal entre los qom. In: Gran Chaco. Ontologias, poder, afectividad, eds. F. Tola, C. Medrano, and L. Cardin, 77-101. Buenos Aires: Asociación Cívil Rumbo Sur.

Milliken, W., B. Albert, and G. Goodwin Gomez. 1999. Yanomami: A forest people. Kew: Royal Botanic Gardens.

Nazarea, V. D., ed. 1999. Ethnoecology: Situated knowledge/located lives. Tucson: University of Arizona Press.

Peralta, P. A. and K. A. Kainer. 2008. Market integration and livelihood systems: A comparative case of three Asháninka villages in the Peruvian Amazon. Journal of Sustainable Forestry 27(1-2): 145-171. https://doi.org/10.1080/ 10549810802225267.

Perrault-Archambault, M. and O. T. Coomes. 2008. Distribution of agrobiodiversity in home gardens along the Corrientes River, Peruvian Amazon. Economic Botany 62(2): 109-126.

Plowman, T. C., A. Leuchtmann, C. Blaney, and K. Clay. 1990. Significance of the fungus Balansia cyperi infecting medicinal species of Cyperus (Cyperaceae) from Amazonia. Economic Botany 44(4): 452-462.

Randall, R. A. and E. Hunn. 1984. Do life forms evolve or do uses for life? Some doubts about 
Brown's universal hypotheses. American Ethnologist 4: 1-26.

Rival, L. M. 2002. Trekking through history. The Huaorani of Amazonian Ecuador. New York: Columbia University Press.

Rojas Zolezzi, E. C. 2014. El morral del colibri. Mitologia, chamanismo y ecologia simbolica entre los ashaninka del oriente peruano. Lima: Libreria Editorial Horizonte.

- 2003. La clasificación Ashaninka de la fauna del piedemonte central: Un caso de diferentes niveles de aproximación. Bulletin de I'nstitut Française d'etudes Andines 32(1): 185212. https://doi.org/10.4000/bifea.6468.

-1997. Origen y clasificación de plantas en el pensamiento mítico Asháninka. Antropologica 15: 255-288.

Santos-Granero, F. 2012. Beinghood and peoplemaking in native Amazonia. HAU: Journal of Ethnographic Theory 2(1): 181-211.

Seeger, A., R. da Matta, and E. Viveiros de Castro. 1979. A construção da pessoa nas sociedades indígenas Brasileiras. Antropologia 32: 2-19.

Shepard, G. H., Jr. 1998. Psychoactive plants and ethnopsychiatric medicines of the Matsigenka. Journal of Psychoactive Drugs 30(4): 321-332.

SICNA. 2016. Directorio 2016 Comunidades Nativas del Perú. Lima: Sistema de Información sobre Comunidades Nativas de la Amazonía Peruana, Instituto del Bien Común.

Stovall, M. E. and K. Clay. 1988. The effect of the fungus, Balansia cyperi Edg., on growth and reproduction of purple nutsedge, Cyperus rotundus L. New Phytologist 109(3): 351-359.

Tessmann, G. 1930. Die Indianer Nordost-Perus, Hamburg, de Gruyter and Co.

Tola, F. 2005. Personas corporizadas, multiplicidades y extensiones: Un acercamiento a las nociones de cuerpo y persona entre los toba (qom) del Chaco argentino. Revista Colombiana de Antrpología 41: 107-134.

-.. 2012. El cuerpo múltiple qom en el universo superpoblado. Indiana 29: 303-328.

Tournon, J. 1991. La clasificación de los vegetales entre los Shipibo-Conibo del Ucayali. Revista Antropológica 9: 119-151.

Tournon, J., S. P. Caúper, and R. O. Urquía. 1998. Los 'piri piri', plantas paradójicas de la Amazonia. Antropologica 16(16): 215-240.

Trotter, R. and M. Logan. 1986. Informant consensus: A new approach for identifying potentially effective medicinal plants. In: Plants in indigenous medicine and diet: Biobehavioral approaches, ed. N. L. Etkin, 91-112. Bedford Hills, New York: Redgrave Publishers.

Tucker, G. C. 1983. The taxonomy of Cyperus (Cyperaceae) in Costa Rica and Panama. Systematic Botany Monographs 2: 1-85.

Udari, L. M. 2018. Medicinal properties of Cyperus species (sedge family, Cyperaceae). Master's thesis 4314, Eastern Illinois University. https:// thekeep.eiu.edu/theses/4314.

Valadeau, C., J. A. Castillo, M. Sauvain, A. F. Lores, and G. Bourdy. 2010. The rainbow hurts my skin: Medicinal concepts and plants uses among the Yanesha (Amuesha), an Amazonian Peruvian ethnic group. Journal of Ethnopharmacology 127(1): 175-192.

Varese, S. 2006. Sal de los cerros. Lima: Fondo Editorial del Congreso del Peru.

Vasquez, M. R and R. D. P. Rojas G. 2016. Clave para indentificar grupos de familias de gymnospermae y angiospermae del Perú. Missouri Botanical Garden. http://www.jbmperu. org/curso/Clave_Identificacion_Plantas.pdf.

Veber, H. 2003. Asháninka messianism. The production of a "black hole" in Western Amazonian ethnography. Current Anthropology 44(2): 183-211.

Velásquez-Pérez, H. and P. Galeano-García 2012. Evaluación fotoquímica y de actividad antioxidante de los rizomas de tres especies del género Cyperus. Momentos de Ciencia 9(1): 15-21.

Vickers, W. T. 1976. Cultural adaptation to Amazonian habitats: The Siona-Secoya of Eastern Ecuador. Graduate dissertation, University of Florida.

Vilaça, A. 2005. Chronically unstable bodies: Reflections on Amazonian corporalities. Journal of the Royal Anthropological Institute 11(3): 445-464.

Weiss, G. 1969. The cosmology of the Campa Indians from Eastern Peru. Ph.D. dissertation, University of Michigan.

Wezel, A. and J. Ohl. 2005. Does remoteness from urban centres influence plant diversity in homegardens and swidden fields? A case study from the Matsiguenka in the Amazonian rain forest of Peru. Agroforestry Systems 65: 241-251.

Zoghbi, M.G. B. das, E. H. A. Andrade, L. M. M. Carreira, and E. A. S. Rocha. 2008. Comparison of the main components of the essential oils of "priprioca": Cyperus articulatus var. articulatus L., C. articulatus var. nodosus L., C. prolixus Kunth and C. rotundus L. Journal of Essential Oil Research 20(1): 42-45. 